Article

\title{
Trends in Agricultural Land in EU Countries of the Baltic Sea Region from the Perspective of Resilience and Food Security
}

\author{
Pontus Ambros * (D) and Madeleine Granvik \\ Natural Resources and Sustainable Development, Department of Earth Sciences, Uppsala University, \\ 75236 Uppsala, Sweden; madeleine.granvik@balticuniv.uu.se \\ * Correspondence: pontus.ambros@balticuniv.uu.se; Tel.: +46-18-4711786
}

Received: 21 June 2020; Accepted: 18 July 2020; Published: 21 July 2020

\begin{abstract}
Agricultural land is crucial for the production of food and is, thereby, directly connected to food security. Agriculture is threatened by a multitude of hazards, such as climate change, peak oil, peak soil and peak phosphorus. These hazards call for a more resilient food system that can deliver food security for the global population in the future. In this paper, we analyse the Baltic Sea region's ten European Union (EU) member states, investigating which trends are to be found in statistics between 2005 to 2016 on the development of agricultural land. In our paper, we analyse these trends of agricultural land by looking at three categories of data: (1) utilised agricultural area, (2) number of farms and (3) agricultural labour input. The results showed a trend that agricultural land is increasingly dominated by large farms, whilst over 1 million predominantly small farms have disappeared, and agricultural-labour input has dropped by more than $26 \%$. These trends point towards a mechanisation of production, where larger and less labour-intensive farms take over production. This could partly be due to the EU common agricultural policy, which tends to favour large farms over small. Further, we argue for the importance of farm-size diversity, and about the dangers to food security that a system that is dominated by large farms possesses. Lastly, we conclude that the concept of resilience needs to be better included in policy development and food-system planning, and that more research needs to be done, analysing how existing agricultural policies impact the parameters studied in this paper.
\end{abstract}

Keywords: agricultural land; food security; farm scale; Baltic Sea region; EU; resilience; farm labour; industrialised farming; climate change

\section{Introduction}

Agricultural land produces food, and it is crucial to understand its structures and trends in relation to the food system as a whole. Recent research and statistics showed that land available for growing food is generally decreasing, which challenges the current agricultural system to provide sufficient access to food [1]. Increased competition concerns other factors than the production of food, where agricultural land is also being used in the production of fibre and bioenergy, as well as being exploited for buildings and roads in the era of urban sprawl. Further research suggested that the loss of agricultural land and its global impact are increasingly unstable from the perspectives of the effects of climate change and the ongoing degradation of natural resources $[2,3]$. In the last decade, agricultural policy has been confronted to a higher degree than ever before by challenges related to climate change, peak oil [4], peak soil [5] and peak phosphorus [6]. Sustaining the management of agricultural land is a vital issue in feeding the population $[2,7,8]$. 


\subsection{Trends and Challenges}

As long as urban populations continue to grow, the challenge of maintaining food security is increasing. In the "How to feed the world 2050" report [2], calculations showed a need for a $70 \%$ increase in food production by 2050. This would require 100-250 million hectares more of agricultural land to cover the lack of food for an estimated world population of more than nine billion people by then. At the same time, it is as well envisaged that different crises can occur in current times and will also occur in the future, affecting food security. Since the global food system is dependent on its supply chain to a great extent, a crisis, such as climate change and global pandemics, could lead to restrictions in the global food market, leading to shortages of food. The COVID-19 pandemic is an example of a crisis that disrupted the food-supply chain, affecting the food security of the poor [9,10]. According to the World Food Program (WFP), 265 million people living in low- and middle-income countries are estimated to live under severe pressure and will suffer from a shortage of food by the end of 2020 [11].

With an increase in world population, urbanisation, pressure on the ecological systems, and kinds of crises, such as pandemics, it is crucial to work for more sustainable and resilient food systems, closer to the consumer, especially in urban settings [12-14]. Scholars claim for a more balanced situation between the current domination of global loops of food systems and regional and local loops. Developing more sustainable and resilient food systems on different scales is crucial in securing access to food today and in the future, in times of peace, crisis and even war [15-23].

\subsection{Agricultural Land in the Context of Resilience for Food Security}

The concept of food security was introduced in 1974, defined by the World Food Conference as the availability of basic food items and their price stability on an international and national level [24]. About two decades ago, 200 definitions of food security were found in the literature [25]. In a report by the Food and Agricultural Organization (FAO), International Fund for Agricultural Development (IFAD) and World Food Program (WFP), food security was defined as a "situation that exists when all people, at all times, have physical, social and economic access to sufficient, safe and nutritious food that meets their dietary needs and food preferences for an active and healthy life". Four food-security dimensions can be identified in this definition: food availability, economic and physical access to food, food utilisation and stability over time [26]. For this paper, the latter interpretation is stressed, with a focus on the stability aspects of food security related to agricultural land. The 2020 edition of the Global Report on Food Crises states that, in 55 countries and territories, the situation by the end of 2019 was that 135 million people faced acute food insecurity. In addition, 183 million people live in stressed food-insecurity conditions, making them a risk group for future severe food insecurity [27].

Various crises, currently and in the future, challenge the food security of the global population. Crises, such as climate change and global pandemics, may lead to shocks that disrupt the crucial functions of socioecological systems and their agents, threatening and challenging food security. Two types of shocks are discussed in the literature, covariate shocks, such as floods or drought that affect a high number of people at the same time, and idiosyncratic shocks, affecting individuals or households, such as diseases or death [28]. In light of the crises of today, such as the pandemic, climate change and the decrease in natural resources and ecosystem services, covariate shocks could be predicted to even increase in the future, resulting in decreased food security. This sets policy and planning for more resilient food systems at the very centre of the current political agenda.

The concept of resilience has been adopted in several disciplines and by several scholars since Holling's influential published paper [29]. Resilience has been central in the policy discourse for sustainable development for more than a decade [30,31]. Moreover, it is used in different contexts related to planning, such as resilient food systems for food security [7]. Resilience in a food-planning context suggests there being socioecological-political systems that hold a given adaptive capacity to relieve disturbances, mitigated by actors learning and understanding the interplay within a system [7]. It is crucial to understand the robustness and weaknesses of food systems and their ability to adapt in times of crisis and shocks [32-34]. 
A closely related concept is localisation, which is a process of adaptation where the aim is to increase the capacity of regions and local areas, such as municipalities and their actors in building resilience. Localisation means to increase the geographic proximity of production, processing and consumption. Closer food loops means to focus on smaller scales of food systems, such as regions and local areas, rather than global food systems $[16,18,19,22,23,35]$. Scholars consider this approach as food systems where social, ecological relations are embedded to a greater extent when compared with industrialised global food systems [36-39].

Béné et al. [40] suggested a resilience framework where capacity is the key concept. Three types of actions related to capacity in building resilience in times of shocks were presented: what to do to assist the system when a shock occurs; what to do to support the system to adapt and decrease the exposure of the shock; and what to do to transform the system to not be vulnerable to the same type of shocks. In creating long-term resilience, the last kind of capacity, transformative capacity, refers to the required prerequisites on the system level for change [40,41]. This paper suggests that adaptive capacity between local actors and transformative capacities in relation to agricultural land includes medium- and long-term mechanisms to develop robustness and resilience in building food security. Adaptive means the ability of actors in a system to cope with change [42]. Pingali et al. [34] suggested four strategies in improving the resilience of a food system: building the farmers' ability to adapt and reorganise in times of crisis; strengthening the diversity of the food system; rebuilding local institutions and traditional support networks; and reinforcing local knowledge about farming. Focusing on reconstructing the capacity of communities to find rapid and flexible solutions to occurring problems and crises gives the local level a crucial role, having significant influence in improving the resilience potential of food systems. Protecting and promoting biodiversity in our existing agricultural systems is also a vital issue to make food systems more resilient [43].

\subsection{Agricultural Land in European Union (EU) Countries of the Baltic Sea Region}

Conditions for producing food are, in general, beneficial in Europe. Agricultural land is found across the continent and, to a great extent, in close proximity to agglomerations. About half of the land is used for agricultural purposes regardless of population density. A possible explanation for this is that the densest areas in population are also the most fertile ones [44]. The current land take is about 252 hectares per day in Europe. The main factor for this happening is due to the urban sprawl [44]. For a decade, the trend in Europe has been an increasing amount seen per resident of artificial surfaces, roads, buildings, parking lots, etc. [45,46]. The EU has taken the initiative to promote and document best practices related to limiting, mitigating and compensating for soil sealing across the member states. In the "guidelines on best practices to limit, mitigate, or compensate soil sealing" [47], the need for the protection of farmland is stressed.

At the same time, issues regarding the meaning of local food systems were highlighted on the political agenda. The European Committee of the Regions, acting as the EU's Assembly of Regions and Local Representatives, has been stressing for a decade the need for a local perspective related to goals for more sustainable and resilient food systems. A result of their work is EU regulation [48] that brings up the importance of short food chains, local food markets and supporting interactions of urban and rural areas. In the common-agricultural-policy (CAP) reform of 2013, short food-supply chains were articulated for the first time [49].

One central feature in developing a CAP within the EU in the 1950s was food security and supplies [50]. However, the CAP is known to favour large- over medium- and small-scale farms [51], which can be questioned from the perspective of building resilience for food security. In the latest decades, agriculture in Europe has faced several challenges, such as the need for more sustainable agricultural systems, increased globalisation, new demands from consumers and, lately, to plan, prepare and transform into more resilient food systems. It and failures of commodity- and price-based policies of recent decades have led to different CAP reforms [52]. Agricultural policy is becoming increasingly territorial related to various internal and external factors, such as farm enlargement, 
multilateral trade negotiations, consumer concerns and environmental impact [53-55]. Since the agricultural sector is less aided by market-price support, multifunctionality has increased in importance for regional development. Multifunctional agriculture can be explained by farm diversification in the sense of focusing on other farm activities than food production, or by specialisation in food production for increased added value [52].

In 2004, eight countries of central and eastern Europe (the Czech Republic, Estonia, Hungary, Latvia, Lithuania, Poland, Slovakia and Slovenia) joined the EU. Six of those countries are located in the Baltic Sea drainage basin. In this study, we are specifically looking at countries that entirely or partly lie within the drainage basin whilst also being an EU member state. Like many other regions, the Baltic Sea region has a complicated and intertwined history. Throughout the Cold War era, the region had a distinct division between the democratic market-liberal West and the authoritarian communist counterpart in the east. For more than half a century, the region was split between two ideologies with separate goals of societal development. With the region entering a new era after the Cold War, global sustainability problems have been ever more present [56], and regional responses were highlighted as a solution to many of these challenges [57-59].

At the same time, there has been ongoing land transformation since the Second World War, where European agricultural land has been shifting towards large-scale farming [60]. However, seen from a European perspective, EU countries of the Baltic Sea region still have somewhat heterogeneous agricultural land, something we explore further in this paper by asking the following question: What trends are to be found from 2005 to 2016 on the development of agricultural land in EU countries of the Baltic Sea region? Results are analysed from the perspective of building resilience and food security. We clarify the trends of three categories of data, describing the total agricultural area in use, number of farms and agricultural labour input, where data are analysed from a farm-size perspective.

\section{Methodology}

\subsection{Data Sources and Method of Data Collection}

Data in this study came from Eurostat [61,62], which is based on the Farm Structure Survey (FSS) for 2005, 2007, 2010, 2013 and 2016, and employment data from all years between 2005 and 2016. The data were compiled and made publicly available by Eurostat, where we analysed the trends of three categories: (1) utilised agricultural area, (2) number of farms and (3) agricultural labour input. Utilised agricultural area (UAA) is defined as arable land currently in production, including permanent crops, grasslands and kitchen gardens. It excludes land in fallow and agricultural land temporarily used for purposes other than farming [63]. We defined a farm in accordance with Eurostat [64], summarised as an independently managed unit that grows crops, has animal production, or produces plant propagation on land. Agricultural labour input (ALI) is measured in annual working units (AWUs), where one AWU corresponds to one full-time employment for a full year [65].

\subsection{Data Analysis Technique}

In the datasets, we analysed all ten EU states within the Baltic Sea Region's drainage basin, namely, the Czech Republic (CZ), Denmark (DK), Germany (DE), Estonia (EE), Latvia (LV), Lithuania (LT), Poland (PL), Slovakia (SK), Finland (FI) and Sweden (SE) (Figure 1). 


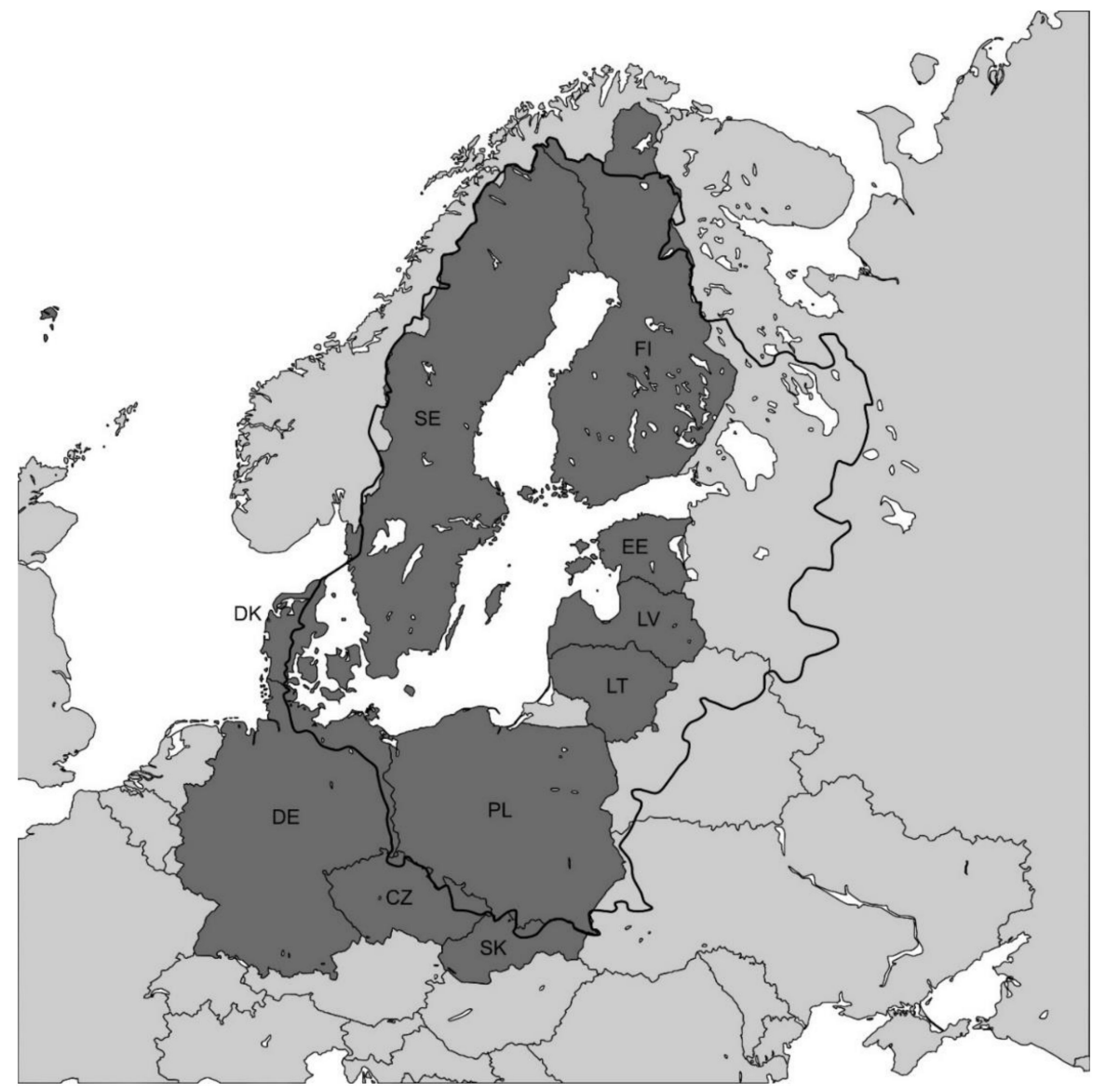

Figure 1. Map of the study area. Darkly shaded areas, territories of ten European Union (EU) states within the Baltic Sea drainage basin (marked with thick black border).

Data from the 2005 FSS were selected as part of the starting year in this analysis leading up to the most recent one in 2016. It was also a period when all ten states had become member states in the European Union (EU), with most of them joining the EU in 2004. UAA and farm data are divided by Eurostat into eight size categories. The dataset was divided into the following sizes; $0,<2,2-4.9,5-9.9$, 10-19.9, 20-29.9, 30-49.9, 50-99.9 and $>100$ ha. In this text, we describe four categories: 0 ha, small, medium and large farms, as shown in Table 1.

Table 1. Eurostat categories and our classification.

\begin{tabular}{cc}
\hline EUROSTAT Categories & Our Definition \\
\hline 0 ha & 0 ha farms \\
\hline$<2$ ha & Small farms \\
\hline $2-4.9$ ha & \\
\hline $5-9.9$ ha & Medium farms \\
\hline $10-19.9$ ha & \\
\hline 20-29.9 ha & Large farms \\
\hline 30-49.9 ha & \\
\hline 50-99.9 ha &
\end{tabular}


The analysis consisted of mostly descriptive statistics based on our selected time frame, territorial boundaries and classification. To compare the ALI of the ten countries, we used the following equation.

$($ AWU/UAA $) * 100=$ agricultural labour input per 100 ha.

where we divided the AWU with total UAA for each country and year and multiplied the results with 100 to obtain a comparable result of labour intensity in the region. The results gave us a comparable number of ALI per hectare.

\section{Results}

\subsection{Utilised Agricultural Area}

In the period, some changes in the overall utilised agricultural area could be seen (Table 2). In the entire region, there was a slight decrease in utilised land (2-6\%) except for the three Baltic states and Slovakia, which all had an increase in UAA. Estonia had the most significant percentage increase in utilised agricultural land with more than $20 \%$, accounting for an actual increase in hectares of 166,170 ha. Latvia had the most substantial actual increase in hectares, increasing its UAA by 229,200 ha or $13 \%$ of its total UAA in 2005 . Lithuania increased its total UAA by $5 \%$ or 132,560 ha. The increase in Slovakia was just over $0.55 \%$ of total UAA, which is 10,330 ha. The largest decrease in UAA percentage was in Sweden, which decreased its UAA by about $5.6 \%$ (or by 179,810 ha). The most considerable reduction in actual hectares was seen in Poland, where 349,230 ha or $2.37 \%$ of total UAA disappeared during the same period. Similar numbers could also be seen in Germany, where 319,900 ha or 1.88\% of total UAA was reduced. On a regional scale, total UAA remained relatively stable, going from $50,749,290$ ha in 2005 to $50,177,100$ ha in 2016, a reduction of just below 1.13\% (Figure 2).

Table 2. Farm composition of utilised agricultural area (UAA) and trends in 2005-2016 per study country.

\begin{tabular}{|c|c|c|c|}
\hline Country & Utilised Agricultural Area (UAA) & Farm Composition and Trends & Appendix A \\
\hline $\mathrm{CZ}$ & $97.12 \%$ & $\begin{array}{l}\text { In the Czech Republic (CZ), a majority ( } 93 \% \text { ) of } \\
\text { UAA has belonged to large farms since } 2016 \text {. } \\
\text { This percentage has remained fairly constant } \\
\text { since that period, with no major changes in UAA } \\
\text { percentage. Actual hectares belonging to large } \\
\text { farms decreased ( }-95,330 \text { ha). The general trend } \\
\text { showed that UAA belonging to medium farms } \\
\text { increased slightly, both in terms of percentage of } \\
\text { total UAA and actual increase of ha. UAA } \\
\text { belonging to small farms decreased with about } \\
0.5 \% \text { of the total UAA or by } 20,420 \text { ha. Total UAA } \\
\text { decreased slightly in } 2005-2016 \text {. }\end{array}$ & Figure A1 \\
\hline DK & $95.56 \%$ & $\begin{array}{l}\text { In Denmark (DK), a majority ( } 85 \% \text { ) of UAA has } \\
\text { belonged to large farms since } 2016 \text {. This is an } \\
\text { increase from } 76 \% \text { in } 2005 \text {. This increase can also } \\
\text { be seen in the actual increase in hectares (182,320 } \\
\text { ha), mainly due to the increase in UAA belonging } \\
\text { to farms of over } 100 \text { ha. The general trend } \\
\text { showed that UAA belonging to small and } \\
\text { medium farms is decreasing both in UAA } \\
\text { percentage and actual ha. Total UAA decreased } \\
\text { during the period by about } 4.5 \% \text {. }\end{array}$ & Figure A2 \\
\hline $\mathrm{DE}$ & $98.12 \%$ & $\begin{array}{l}\text { In Germany (DE), a majority ( } 79 \%) \text { of UAA has } \\
\text { belonged to large farms since } 2016 \text {. This is an } \\
\text { increase from } 73 \% \text { in } 2005 \text {. This increase can also } \\
\text { be seen in the actual increase in hectares }(888,580 \\
\text { ha). The general trend showed that UAA } \\
\text { belonging to small and medium farms is } \\
\text { decreasing both in UAA percentage and in actual } \\
\text { ha. UAA decreased during the period by } \\
\text { about } 1.9 \% \text {. }\end{array}$ & Figure A3 \\
\hline
\end{tabular}


Table 2. Cont.

\begin{tabular}{|c|c|c|c|}
\hline Country & Utilised Agricultural Area (UAA) & Farm Composition and Trends & Appendix A \\
\hline $\mathrm{EE}$ & $120.05 \%$ & $\begin{array}{l}\text { In Estonia (EE), a majority ( } 85 \%) \text { of UAA has } \\
\text { belonged to large farms since } 2016 \text {. This is an } \\
\text { increase from } 73 \% \text { in } 2005 \text {. The increase can also be } \\
\text { seen in the actual increase in hectares ( } 240,090 \text { ha). } \\
\text { The general trend showed that UAA belonging to } \\
\text { small and medium farms is decreasing both in } \\
\text { UAA percentage and actual ha, whilst the overall } \\
\text { UAA increased during the period by over } 20 \% \text {. }\end{array}$ & Figure A4 \\
\hline LV & $113.47 \%$ & $\begin{array}{l}\text { In Latvia (LV), a majority ( } 67 \% \text { ) of UAA has } \\
\text { belonged to large farms since } 2016 \text {. This is an } \\
\text { increase from } 43 \% \text { in } 2005 \text {. This increase can also be } \\
\text { seen in the actual increase in hectares ( } 565,090 \text { ha). } \\
\text { The general trend showed that UAA belonging to } \\
\text { small and medium farms is decreasing both in } \\
\text { UAA percentage and in actual ha. Overall, UAA } \\
\text { increased during the period by about } 13 \% \text {. }\end{array}$ & Figure A5 \\
\hline PL & $97.63 \%$ & $\begin{array}{l}\text { In Poland (PL), a majority }(40 \%) \text { of UAA has } \\
\text { belonged to medium farms since } 2016 \text {. This is a } \\
\text { decrease from } 41 \% \text { in } 2005 \text {. This decrease can also } \\
\text { be seen in the actual decrease in hectares ( }-271,920 \\
\text { ha). The general trend showed that UAA belonging } \\
\text { to small and medium farms decreased during the } \\
\text { period both in UAA percentage and in actual ha. } \\
\text { At the same time, UAA belonging to large farms } \\
\text { has been increasing both in percentage (from } 23 \% \\
\text { to } 32 \% \text { ) and actual hectares (1,085,010 ha). Overall, } \\
\text { UAA decreased during the period by about } 2.5 \% \text {. }\end{array}$ & Figure A7 \\
\hline FI & $97.13 \%$ & $\begin{array}{l}\text { In Finland (FI), a majority of UAA has belonged to } \\
\text { large farms ( } 67 \% \text { ) since } 2016 \text {. This is an increase } \\
\text { from } 49 \% \text { in } 2005 \text {. This increase can also be seen in } \\
\text { the actual increase in hectares ( } 377,440 \text { ha). The } \\
\text { general trend showed that UAA belonging to small } \\
\text { and medium farms decreased both in percentage } \\
\text { and actual hectares. Overall, UAA decreased } \\
\text { during the period by almost } 3 \% \text {. }\end{array}$ & Figure A9 \\
\hline SE & $94.37 \%$ & $\begin{array}{l}\text { In Sweden (SE), a majority of UAA has belonged to } \\
\text { large farms ( } 76 \% \text { ) since } 2016 \text {. This is an increase } \\
\text { from } 71 \% \text { in } 2005 \text {. The increase can also be seen in } \\
\text { the actual increase in hectares ( } 23,920 \text { ha). The } \\
\text { general trend showed that UAA belonging to } \\
\text { medium farms decreased both in percentage (from } \\
24 \% \text { to } 19 \% \text { ) and actual hectares (-204,300 ha). } \\
\text { UAA belonging to small farms remained fairly } \\
\text { stable during the period, even increasing slightly, } \\
\text { both in percentage (from } 4.2 \% \text { to } 4.6 \% \text { ) and in } \\
\text { actual hectares ( } 570 \text { ha). Overall, UAA decreased } \\
\text { the most of all countries in this study, dropping } \\
\text { during the period by almost } 6 \% \text {. }\end{array}$ & Figure A10 \\
\hline
\end{tabular}




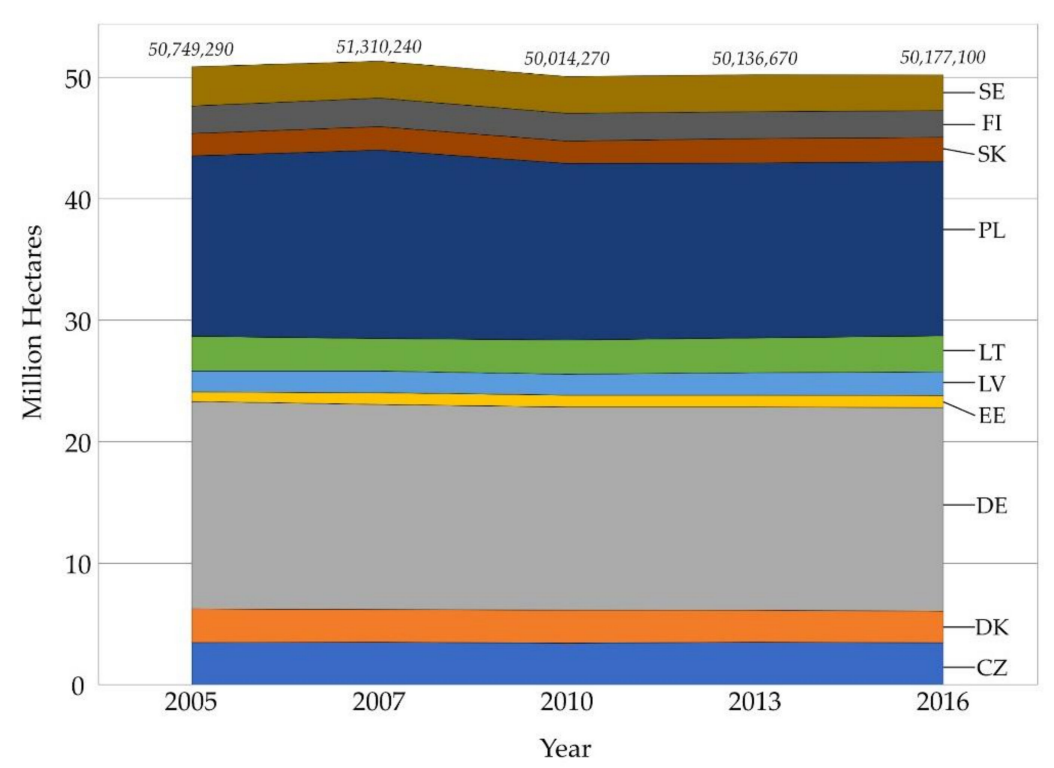

Figure 2. Total utilised agricultural area (UAA) of ten European Union (EU) countries in the Baltic Sea region. Each layer indicates one country in the study. The number at the top of the graph shows the total UAA of the ten countries.

Broken down into the eight Eurostat categories, we can see that, over time, all countries had an increase in UAA belonging to large farms, and most states had a decrease in UAA belonging to medium farms, except for the Czech Republic and Slovakia that showed opposite trends (Figure 3). UAA belonging to small farms decreased all over the region, except for Sweden, which had a slight increase of 570 ha. All countries except for Poland had the majority of their agricultural land taken up by large farms (Table 2). States with the highest percentage of UAA for large farms were the Czech Republic (93\%) and Slovakia (93\%). Although several of the countries showed minor differences (Table 2), the major trend in the region was that UAA belonging to large farms increased. In contrast, UAA belonging to small and medium farms decreased, indicating a possible transformation towards more large-scale farming practices throughout the region (Figure 3).

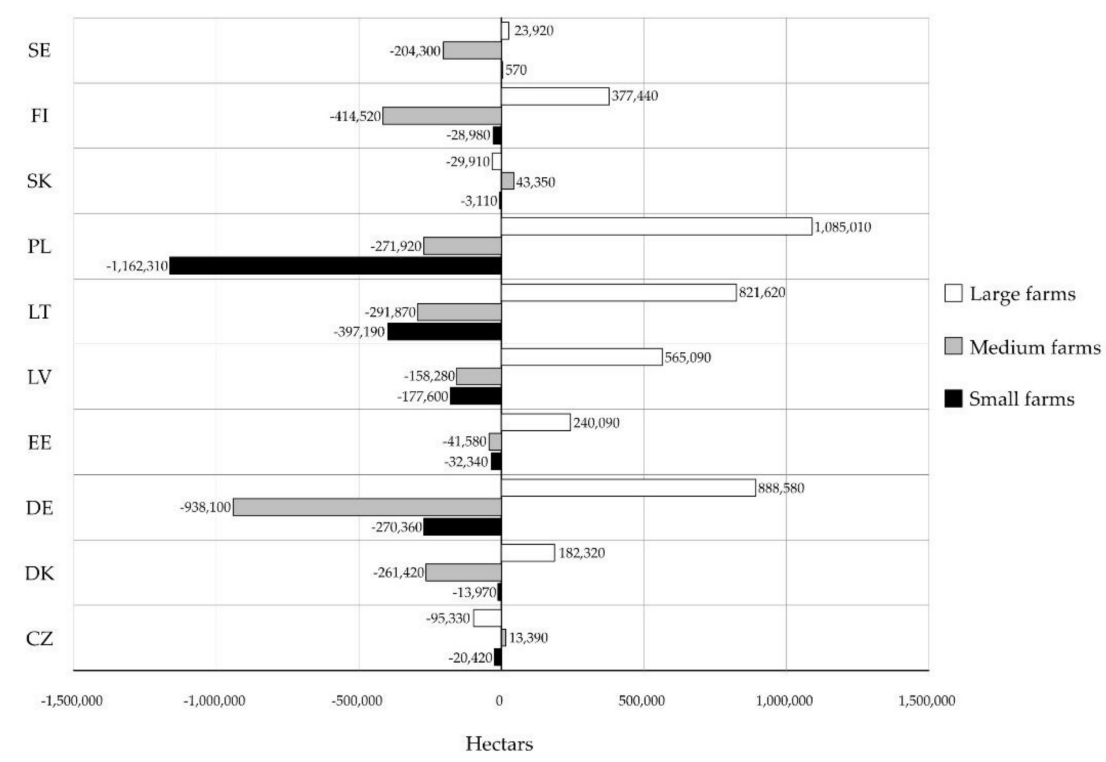

Figure 3. Differences in UAA in 2005-2016, broken down into classifications of small, medium and large farms, showing how each class in each country changed its UAA coverage during the period. 


\subsection{Number of Farms}

The total numbers of farms were derived from Eurostat [62] and are presented in actual numbers of farms. The data also included 0 ha farms, which are those that during the FSS had no active UAA but still practised some farming [64].

All countries showed an overall decline in the number of farms, with a regional decrease of $41 \%$. Primarily, small and medium farms have been disappearing, whilst the number of large farms has been increasing in all countries but Sweden and Denmark, where they decreased by 17\% and 25\%, respectively (Table 3 and Figure 4a,b). However, in both Sweden and Denmark, the largest farms ( $>100$ ha) have been increasing (Table 2). As shown in Table 2, all countries had an overall decline in the number of farms, ranging between $63 \%$ and $17 \%$. In actual numbers, the most substantial decrease took place in Poland, where over 1 million small farms and more than 30 thousand medium farms disappeared in the period. Slovakia $(-45,000)$, Latvia $(-50,000)$, Lithuania $(-88,000)$ and Germany $(-79,000)$ also showed significant decreases in small farms, along with a big reduction in medium German farms $(-37,000)$.

Table 3. Difference in percentage in farm categories for each country and the entire region.

\begin{tabular}{cccccc}
\hline & 0 ha & Small & Medium & Large & All farms \\
\hline SE & $-24 \%$ & $-9 \%$ & $-22 \%$ & $-17 \%$ & $-17 \%$ \\
FI & $-4 \%$ & $-43 \%$ & $-38 \%$ & $10 \%$ & $-30 \%$ \\
SK & $-18 \%$ & $-74 \%$ & $93 \%$ & $28 \%$ & $-63 \%$ \\
PL & $-48 \%$ & $-49 \%$ & $-9 \%$ & $66 \%$ & $-43 \%$ \\
LT & $217 \%$ & $-45 \%$ & $-38 \%$ & $83 \%$ & $-41 \%$ \\
LV & $-46 \%$ & $-56 \%$ & $-29 \%$ & $39 \%$ & $-46 \%$ \\
EE & $933 \%$ & $-55 \%$ & $-32 \%$ & $30 \%$ & $-40 \%$ \\
DE & $197 \%$ & $-55 \%$ & $-23 \%$ & $0 \%$ & $-29 \%$ \\
DK & $110 \%$ & $-22 \%$ & $-44 \%$ & $-25 \%$ & $-32 \%$ \\
CZ & $-66 \%$ & $-62 \%$ & $5 \%$ & $12 \%$ & $-37 \%$ \\
Region & $-18 \%$ & $-50 \%$ & $-19 \%$ & $9 \%$ & $-41 \%$ \\
\hline
\end{tabular}

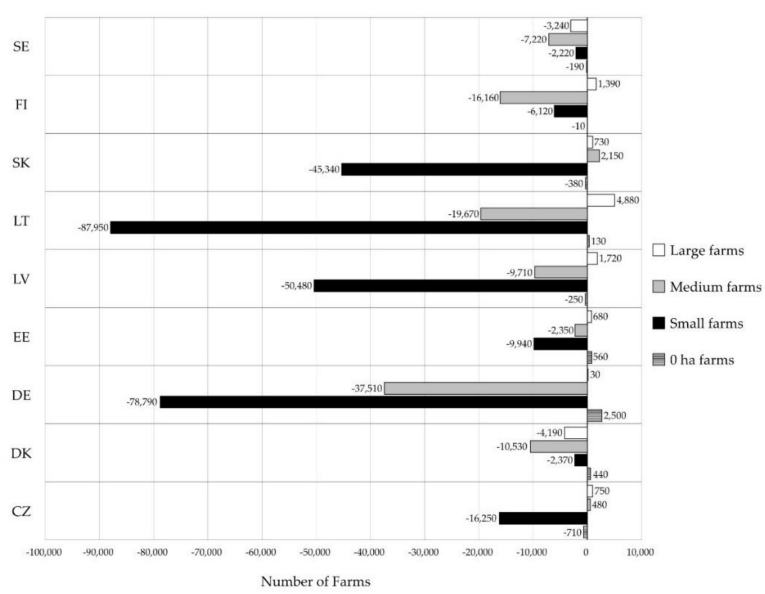

(a)

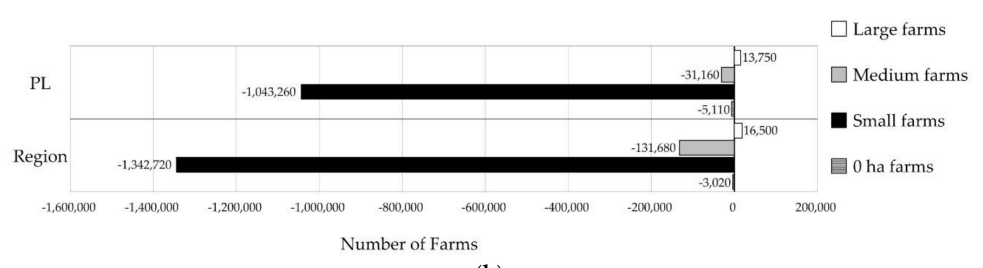

(b)

Figure 4. Difference in the number of farms between 2005-2016 in (a) all countries except for Poland and (b) in Poland and in the region as a whole, broken down into classifications of 0 ha, small, medium and large farms, showing how each class in each country changed during the period. 
Sweden had the smallest percentage decrease in the number of farms, with an overall decline of $17 \%$. In Sweden, it was mainly medium farms that decreased (-7000). Across the region, 1,460,920 farms disappeared in the period, a majority of those small farms $(1,342,720)$, followed by medium $(131,680)$ and 0 ha farms (3020). At the same time, large farms increased by 16,500 (Figure $4 b$ ).

\subsection{Agricultural Labour Input}

Total agricultural labour input (ALI) has been decreasing all over the region during the period, with a total of 962,000 AWUs (Figure 5). The most significant losses could be seen in Poland (-616,000 AWUs), Germany (-103,000 AWUs) and Latvia (-62,000 AWUs).

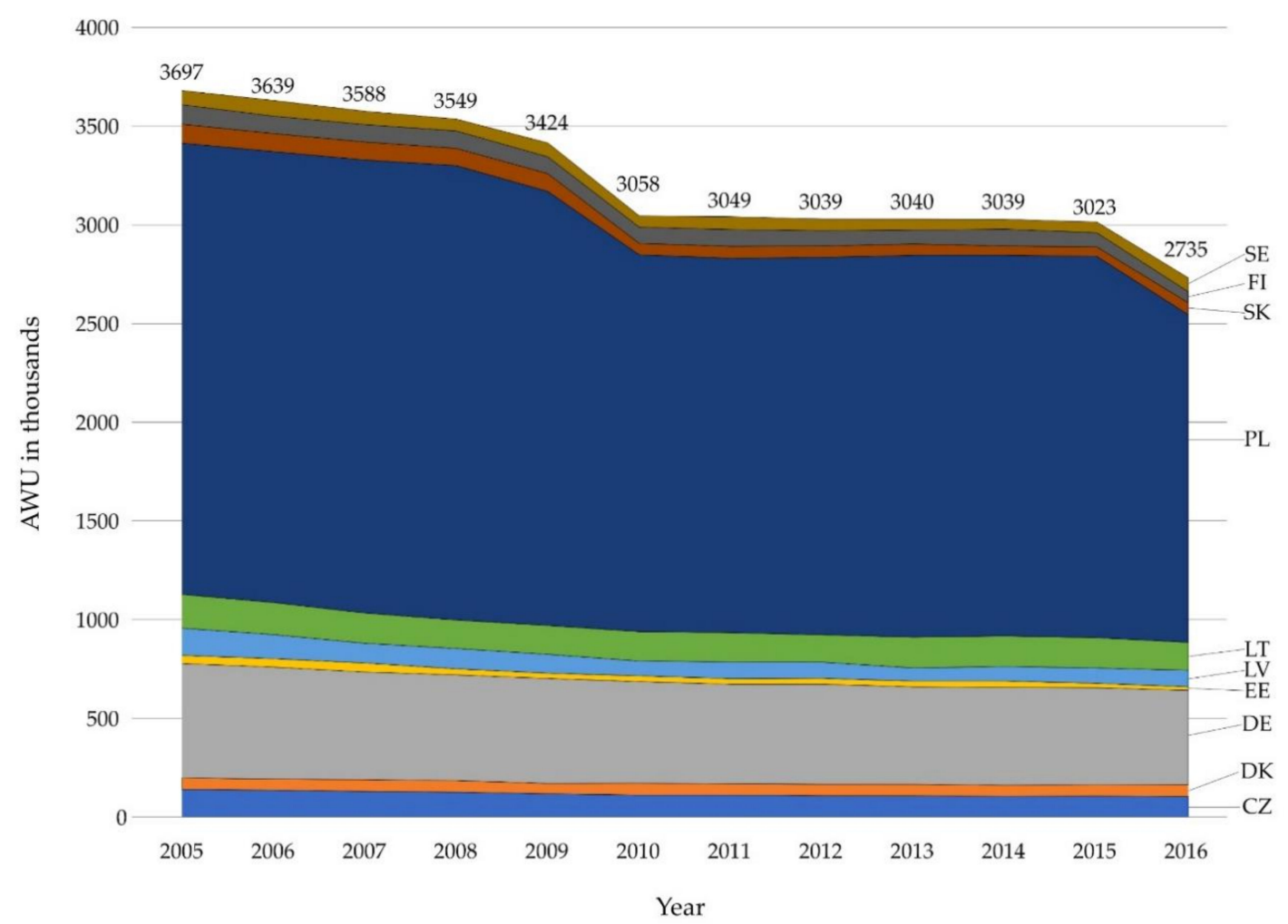

Figure 5. Total agricultural labour input (ALI) of ten EU countries in the Baltic Sea region between 2005-2016. Each layer indicates one country in the study. Numbers at the top of the graph show the total ALI of the ten countries. Numbers shown in thousands of annual working units (AWUs).

When looking at ALI per hectare, we used the AWU/100 ha unit of UAA. All countries saw a decline in the AWU/100 ha of UAA (Table 4). In 2005, Poland had the highest labour intensity per hectare, with 15.53 AWU/100 ha of UAA. In 2016, the number was still the highest in the region, although having dropped to 11.63 AWU/100 ha of UAA (Table 4 and Figure 6c). Latvia had the second-highest ALI per hectare in 2005, with 8.12 AWU/100 ha of UAA, but saw the most significant drop in the region, down to $3.95 \mathrm{AWU} / 100$ ha of UAA, which was a 51\% decrease (Table 4 and Figure 6 b). The most considerable percentage decrease was observed in Estonia, where labour intensity per hectare dropped by 55\%, from 4.56 to 2.04 AWU/100 ha (Table 4 and Figure 6b). Sweden and Denmark already had low labour intensity per hectare in 2005, which remained low throughout the period, only decreasing slightly with -20.43 and -0.22 AWU/100 ha of UAA, respectively (Table 4 and Figure 6b). No country saw an increase in ALI per hectare (Figure 6a-d). 
Table 4. Labour intensity per hectare measured in AWU/100 ha of UAA.

\begin{tabular}{cccccccc}
\hline & \multicolumn{3}{c}{ Year } & & \multicolumn{3}{c}{ Change in 2005-2016 } \\
\hline & $\mathbf{2 0 0 5}$ & $\mathbf{2 0 0 7}$ & $\mathbf{2 0 1 0}$ & $\mathbf{2 0 1 3}$ & $\mathbf{2 0 1 6}$ & Percentage & Value \\
\hline CZ & 3.91 & 3.61 & 3.12 & 3.01 & 3.02 & $-23 \%$ & -0.89 \\
\hline DK & 2.32 & 2.21 & 2.05 & 2.01 & 2.10 & $-9 \%$ & -0.22 \\
\hline DE & 3.42 & 3.27 & 3.12 & 3.01 & 2.87 & $-16 \%$ & -0.55 \\
\hline EE & 4.56 & 3.63 & 2.70 & 2.33 & 2.04 & $-55 \%$ & -2.52 \\
\hline LV & 8.12 & 6.05 & 4.78 & 4.41 & 3.95 & $-51 \%$ & -4.17 \\
\hline LT & 6.22 & 5.96 & 5.23 & 5.06 & 5.09 & $-18 \%$ & -1.13 \\
\hline PL & 15.53 & 14.86 & 13.25 & 13.44 & 11.63 & $-25 \%$ & -3.90 \\
\hline SK & 5.26 & 4.71 & 2.96 & 2.85 & 2.58 & $-51 \%$ & -2.68 \\
\hline FI & 4.18 & 3.90 & 3.58 & 3.33 & 3.00 & $-28 \%$ & -1.18 \\
\hline SE & 2.37 & 2.19 & 2.13 & 2.04 & 1.94 & $-18 \%$ & -0.43 \\
\hline Regional & 7.28 & 6.99 & 6.11 & 6.06 & 5.45 & $-25 \%$ & -1.83 \\
\hline
\end{tabular}

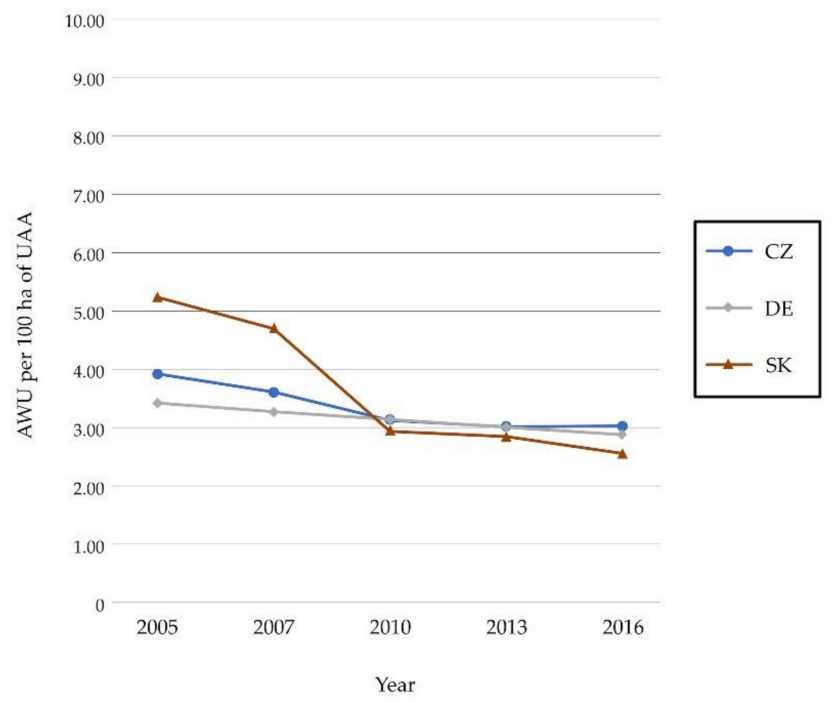

(a)

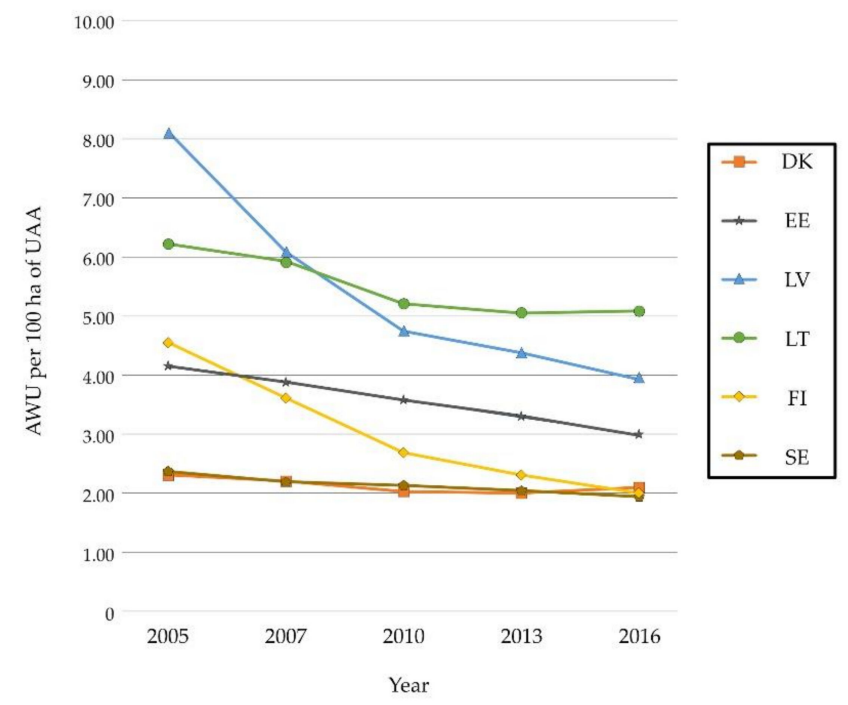

(b)

Figure 6. Cont. 


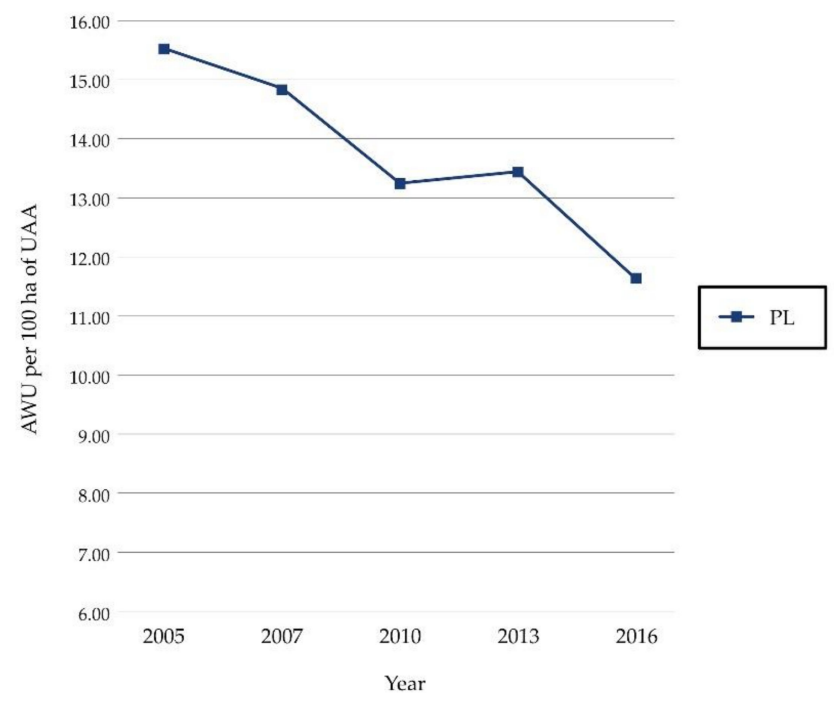

(c)

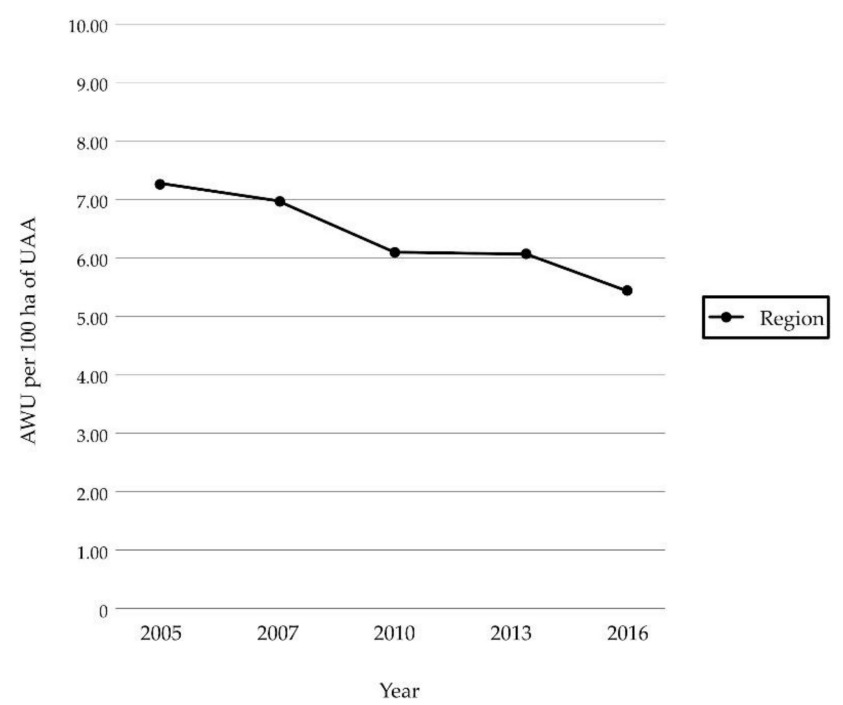

(d)

Figure 6. Labour intensity per 100 ha of UAA in (a) Czech Republic (CZ), Slovakia (SK) and Germany (DE); (b) Denmark (DK), Estonia (EE), Latvia (LV), Lithuania (LT), Finland (FI) and Sweden (SE); (c) Poland (PL); and (d) region as a whole, measured in AWU per 100 ha of UAA.

\section{Discussion}

\subsection{Elaborated Trends from Historic, Current and Future Perspectives}

Our results showed that all countries in the study either had a majority of agricultural land belonging to large farms or showed trends that they were heading towards the majority belonging to large farms. This is not a surprising trend, which further strengthens an already documented pattern described by van Zanten et al. [60]. The pattern of more large farms is also well-reflected in the decline in the number of small and medium farms, as well as declining ALI. This not only suggests a change in farm scale but also an industrialisation of farms where manual labour is being mechanised.

The modern agricultural history of the region can partly explain the trends that we show in this paper. The break-up of the Soviet Union in the early 1990s impacted the agricultural land of former communist states in different ways. During its communist era, Poland had many small farm producers, something that remains until this day [51]. This would explain why Poland is a country with such broad 
diversity in farm sizes, and why it sticks out in comparison to other countries in this study. Poland, unlike the Soviet Union, did not largely communise its agricultural sector during its communist era, but instead allowed a majority of land to be owned by small private farms [51,66]. However, conditions for employment have changed due to structural changes in agriculture. Work outside the farm is the reality for about half of the family members of agricultural families [67], something that was also visible in our results. Poland and Lithuania showed the most significant diversity in farm sizes in the UAA, with large percentages of the UAA belonging to small and medium farms. The numbers suggested, however, that these countries are also moving towards more large-scale farming. Both countries have small farms making up for a large share of UAA, with farms smaller than 5 ha covering $28 \%$ of Poland's UAA and $14 \%$ of Lithuania's UAA. Trends showed a slight increase in land share taken up by farms larger than 30 ha in both countries, indicating a shift towards large-scale farming.

Compared to Poland, the three Baltic states of Estonia, Latvia and Lithuania had a reprivatisation of state-owned farms, where mainly family farmers took over the land, fragmenting former large collective farms from the Soviet era $[51,68]$. These smaller farms have been gradually merging with larger farms, a process that was likely sped up by the countries joining the EU in $2004[51,68]$. According to our results, this process has been the fastest in Estonia, which, out of the three Baltic countries, had the highest percentage of its UAA belonging to large farms.

Similar to the situation in the Baltic states, the Czech Republic and Slovakia used to have large parts of their land owned by collective state farms during their communist era. Unlike the Baltic states, many of those large farms were taken over by companies in the early 1990s [51]. This explains why both of these countries had over $90 \%$ of their UAA belonging to large farms.

State socialism never impacted the three Nordic countries and the western parts of Germany. Thus, it is not surprising that these countries produced a different result compared to the neighbouring countries from the former Eastern Bloc. Denmark, Sweden, Finland and Germany all showed trends where small- and medium-scale farming has been disappearing, benefitting larger farms. In Sweden, these trends have been ongoing since the Second World War, with declining small farms often as a result of farm mergers and reforestation [69,70]. A discontinuation in that trend could be seen in Sweden, where small farms increased their share of UAA by 570 ha. This could partly be explained by increased interest in local food among different actors in the food chain, as well as an increased interest in alternative local-food systems among consumers [71]. Germany, Sweden, Denmark and Finland all had very few small and medium farms compared to the other countries. This could both be explained by a more extended period of market-capital influences and being influenced by the CAP over longer periods. It is perhaps best symbolised by a historical comparison of rural development in Estonia and Sweden, where Sweden transitioning from small family farms to medium and large farms mostly took place in the 1960s [69]. In comparison, similar trends have been present in Estonia since the 2000s [68].

In our results, we see that the region is transforming towards more large-scale farming, where larger farms ( $>100 \mathrm{ha}$ ) are becoming increasingly common in agricultural land. Diversity in farm composition is, however, different in different countries, as they are at different stages in the process towards more homogeneous European agricultural land, dominated by large mechanised farms.

\subsection{Building Resilience for Future Food Security}

The EU's common agricultural policy (CAP) has been in force during the entire period of our study. At the start of the period, the Baltic states, Poland, the Czech Republic and Slovakia had been under the direct influence of the CAP for about one year. The CAP had influenced the Nordic countries and Germany for several more years at this point. As seen throughout the period, small farms were significantly reduced in all countries, a trend that is often blamed on the uneven distribution of financial support from the CAP, which favours large over smaller farms $[51,66]$.

Agricultural land in the region moving towards larger farms and greater industrialisation raises an essential question regarding food-system resilience and food security. In light of climate change, these questions are likely to become relevant, as the region will suffer from more unpredictable weather 
and climate-induced stresses [72,73]. Having more resilient food systems that ensure food security on a socioecological level for its population is, therefore, essential. There are arguments on whether food security can be improved through the technological development of the present system [74], or if more fundamental changes towards a polyculture small-farm system are preferable [15]. One example that speaks of the latter is the exceptional drought that struck Russia in 2010. Russia, one of the largest global wheat producers and exporters, also has large shares of its agricultural land belonging to megafarms of several 100 ha [75]. When the drought struck Russia in 2010, internal food supply was favoured and wheat exports stopped entirely, causing global food prices to spike [76]. With several countries relying on food imports from Russia $[75,76]$, these price fluctuations caused global food prices to increase. With large-scale monoculture farming being prone to failure due to climate-change-related events, some studies suggested that small polyculture or agroecological farms are more adaptive and resilient $[15,77,78]$. Globally, small farms mostly consist of subsistence farmers that significantly contribute to global food security [13]. These small farms are, however, often threatened by the expansion of large farms [13]. With many large farms producing food for a global market, as shown in examples from both the United States and Russia [75,79], it is not guaranteed that the food will benefit local populations.

Small, medium and large farms are all needed to compose a resilient system that enables food security on many scales. Small farming operations are often considered inefficient but can be integrated into modern food-supply chains, as has been proven in the case of Poland [51]. With small and medium farms in decline, there is a need to preserve these farms, allowing for greater farm-scale variations, since these, in turn, provide food security on different scales. Transformation towards large-scale industrialised farming has gone far in Nordic countries, Germany, the Czech Republic and Slovakia. Still, there are indications that these trends might shift, with small farms increasing in Sweden. The Baltic states and Poland are already diverse in terms of farm size, but that might not be the case in the future if the current trend continues. Although the trends seem to be unbroken, we might be in a time of change, with ongoing discussions to strengthen systems with shorter supply chains and more localised production [80].

\section{Conclusions}

First, this study confirmed the already well-grounded trend that countries in the region are moving towards more industrialised large-scale food production. This was seen in measuring UAA, the number of farms and ALI. In the region, over 1 million farms and over 1 million AWUs have disappeared, suggesting that these trends are towards the mechanisation of agriculture. A common factor for all countries in the study has been them being EU members, and, thereby, influenced by the CAP. It is argued that the CAP favours larger farms, forcing the closure of small farms.

Second, the general trend showing that the number of farmers is decreasing raises questions of competence and knowledge for future farming. Who takes over when the current generation of farmers retire? Increased multifunctional and diversified farming is suggested, having an intrinsic value from the perspective of building resilience in the food system. Pluriactivities can be seen as a survival strategy in keeping farmers in the agricultural sector and attracting younger generations that do not tend to consider being a farmer as a living alternative. A multifunctional approach could open up several important strategies for the survival of individual farmers, as well as local communities, regions, countries, in a sense being producers of different agricultural services, not the least food, seen in a future food-security perspectives.

Third, our conclusion suggests that the region is striving towards greater farm-scale diversity, and is taking measures to conserve the remaining small and medium farms. Such action needs a reformulation of the CAP, with equal support to farms of different sizes. It also requires a more inclusive approach to small farmers from the food supply chain, much like the one in Poland.

Lastly, on a societal level, societies require more than productive and functioning farms to uphold a resilient food system. In creating long-term resilience, building adaptive and transformative capacities 
between local actors is crucial. This means actors, such as planners, policymakers, farmers, processors, retailers and consumers, who can cope with change. We stress the relevance of the resilience framework suggested by Béné et al. [40], where capacity is the keyword, and three types of actions are related in building resilience in times of shocks: (1) what to do to assist the system when a shock occurs, (2) what to do to support the system to adapt and decrease the exposure of the shock and (3) what to do to transform the system not to be vulnerable to the same type of shocks. In creating long-term resilience, the last kind of capacity, transformative capacity, refers to the prerequisites on the system level for change; here, this is the food system in the context of different scales and related to CAP.

In this paper, we have focused on analysing trends and tendencies of the agricultural development in the ten EU countries of the Baltic Sea region. Ultimately, we argue that the parameters analysed in this paper are the main parameters that impact both resilience and food security. We recommend a more in-depth analysis of the CAP and national agricultural policies in the ten studied countries, investigating further how these policies impact on the parameters. Such a study would enable policy recommendations and implementation in practice.

Author Contributions: Both authors have contributed to the concept and writing of the paper. Data compiling and analysis was made by PA. The results were analyzed by both authors. All authors have read and agreed to the published version of the manuscript.

Funding: This research received no external funding.

Acknowledgments: We would like to thank guest editor Piotr Prus for his kind assistance and fast communication leading up to the submission of this paper. We would also like to thank the anonymous reviewers that gave constructive comments on our paper.

Conflicts of Interest: The authors declare no conflict of interest.

\section{Appendix A Composition of Utilised Agricultural Area for Each Country}

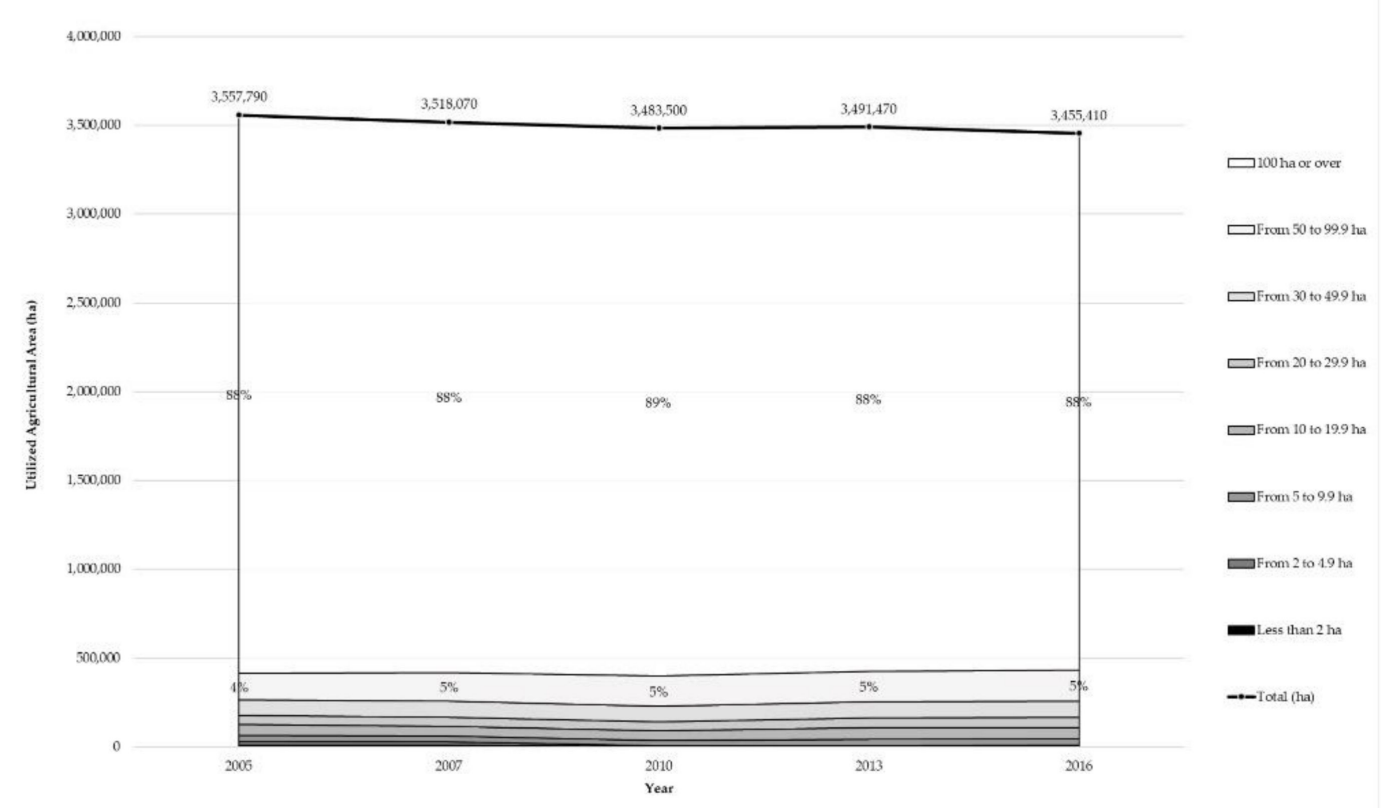

Figure A1. Composition of utilised agricultural area (UAA) 2005-2016 in the Czech Republic. Total numbers show the total UAA in hectares. Categories are represented in percentages of the total UAA as of each year. 


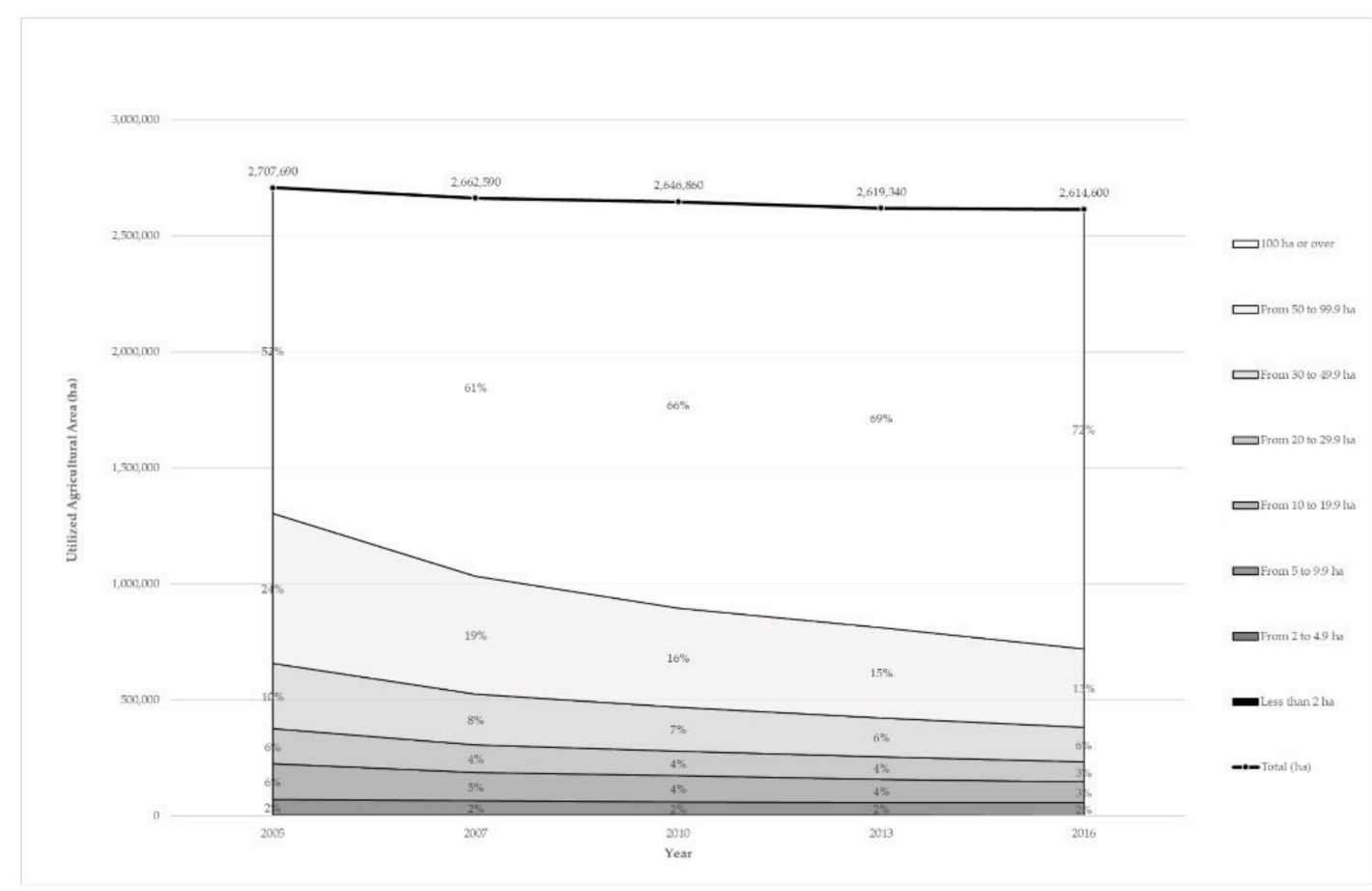

Figure A2. Composition of utilised agricultural area (UAA) 2005-2016 in Denmark. Total numbers show the total UAA in hectares. Categories are represented in percentages of the total UAA as of each year.

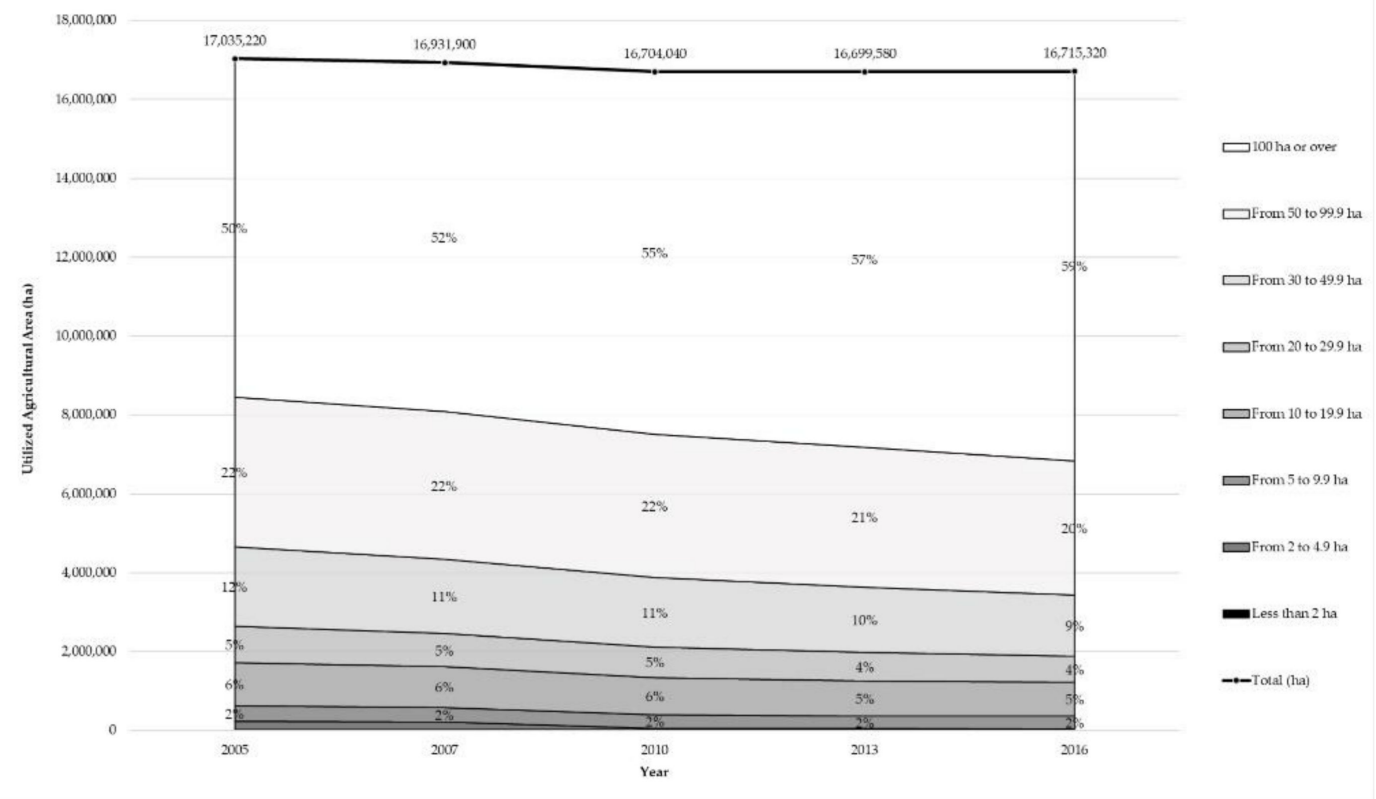

Figure A3. Composition of utilised agricultural area (UAA) 2005-2016 in Germany. Total numbers show the total UAA in hectares. Categories are represented in percentages of the total UAA as of each year. 


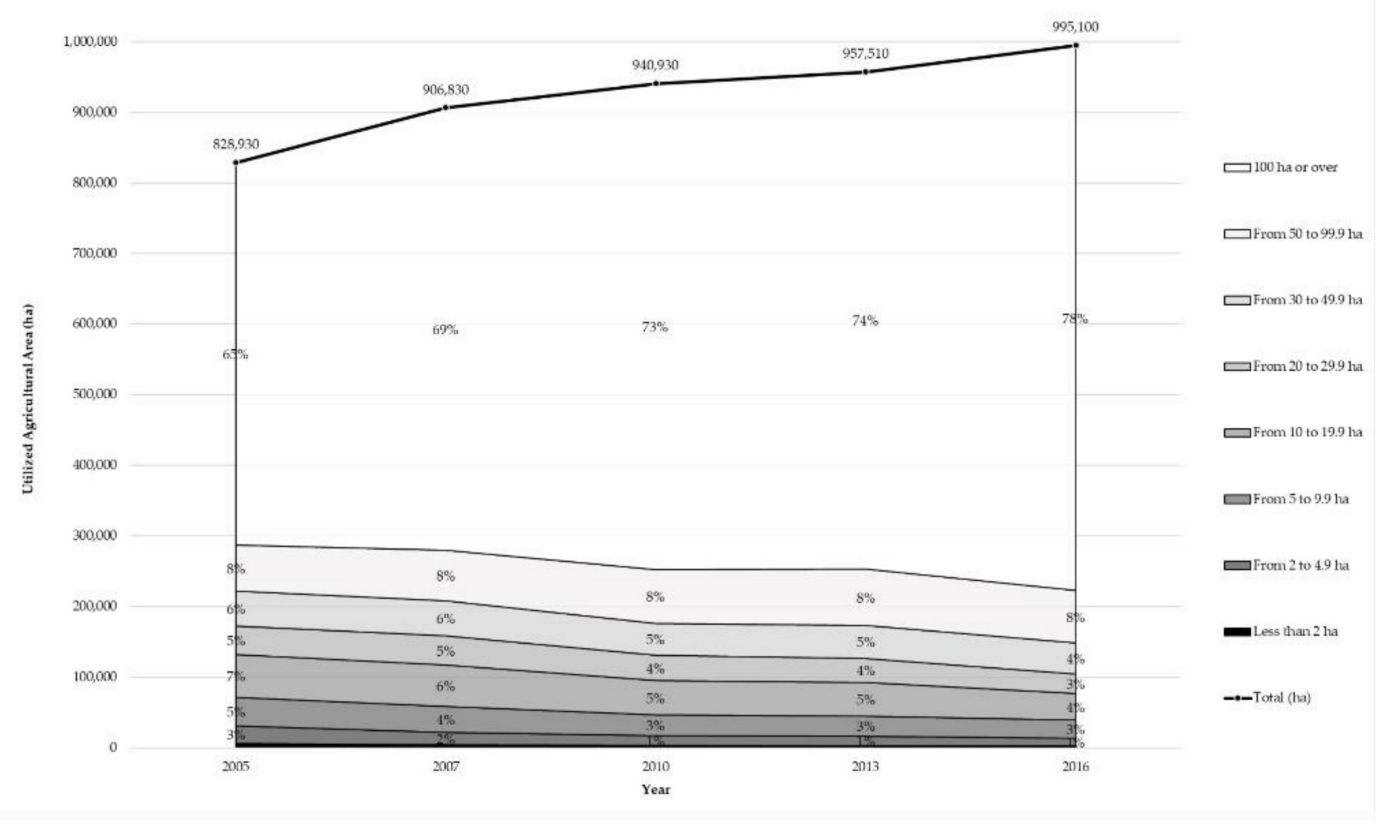

Figure A4. Composition of utilised agricultural area (UAA) 2005-2016 in Estonia. Total numbers show the total UAA in hectares. Categories are represented in percentages of the total UAA as of each year.

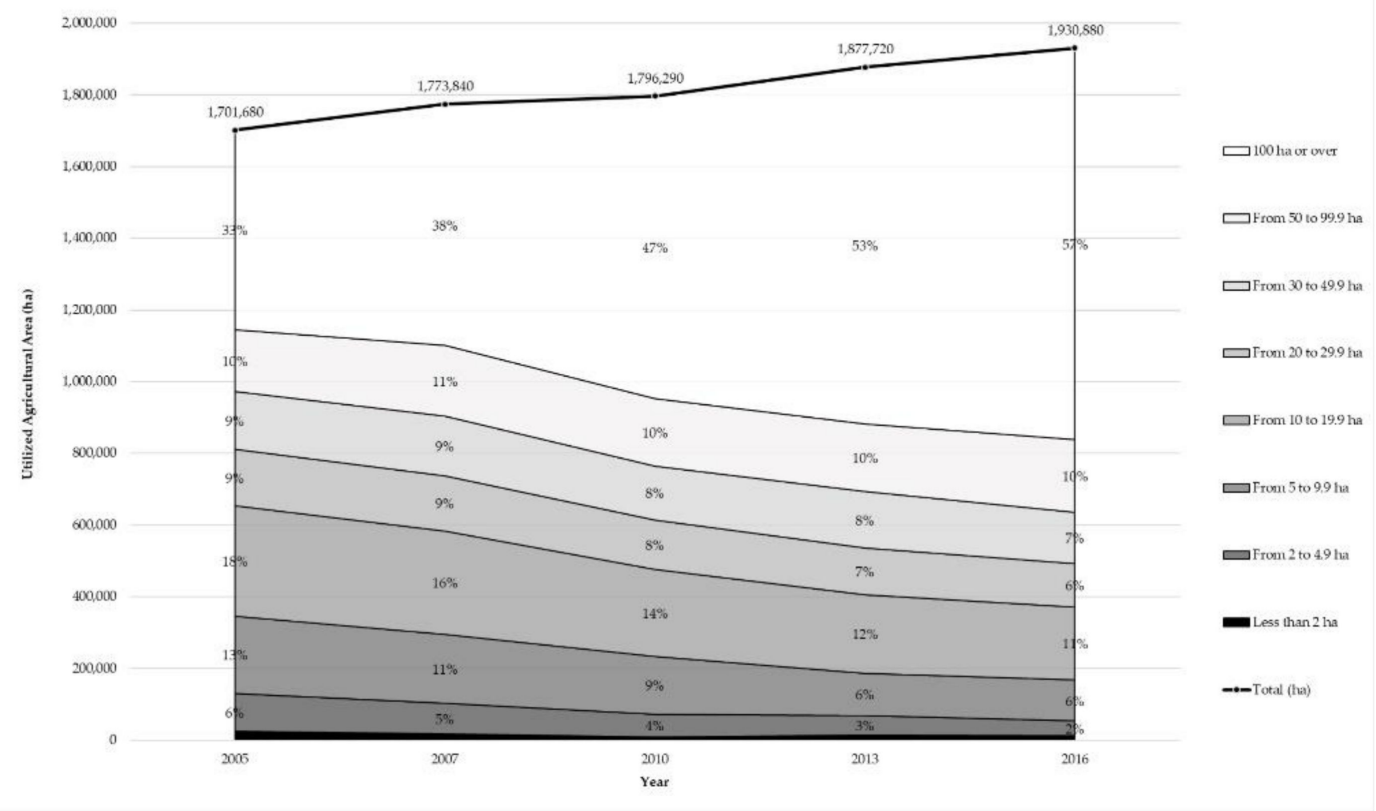

Figure A5. Composition of utilised agricultural area (UAA) 2005-2016 in Latvia. Total numbers show the total UAA in hectares. Categories are represented in percentages of the total UAA as of each year. 


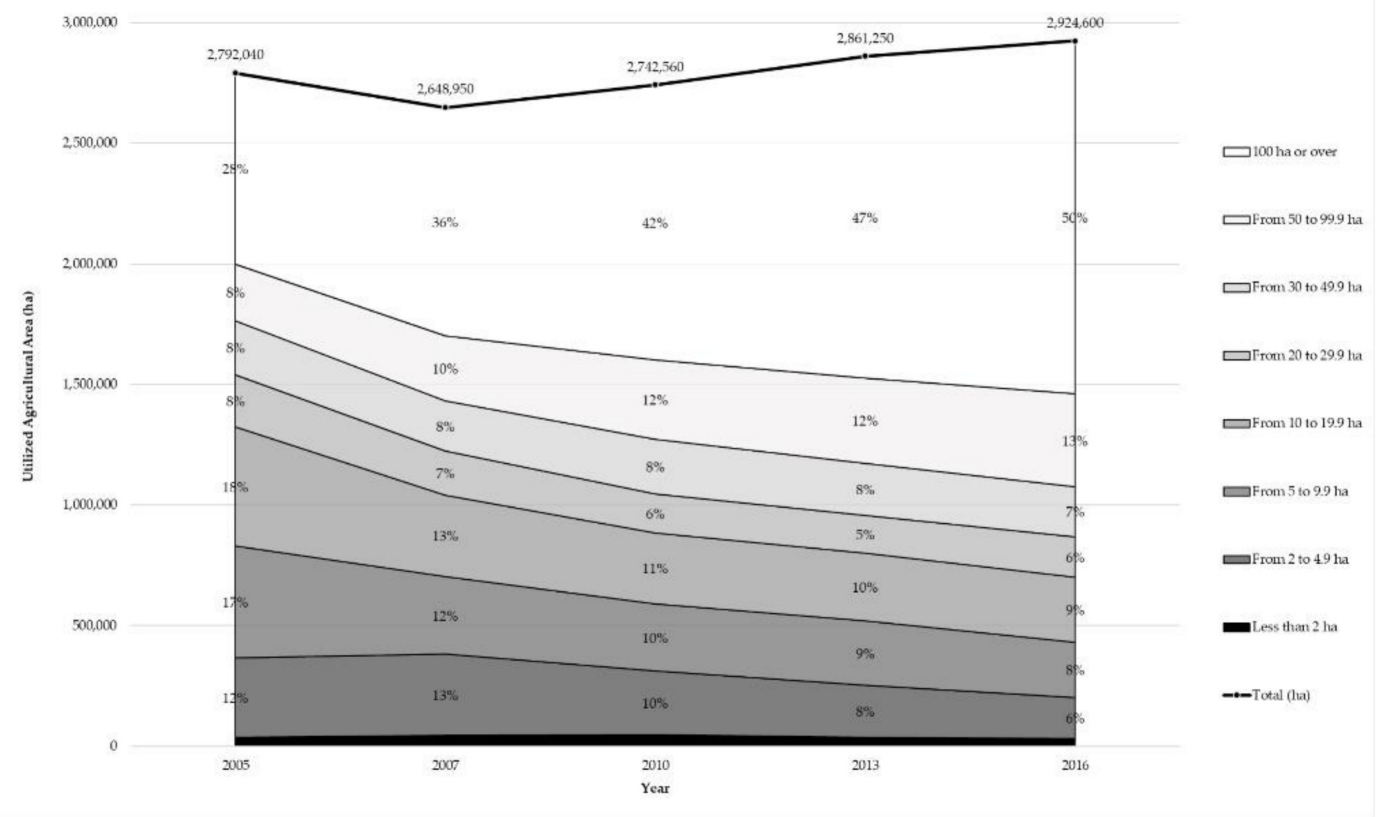

Figure A6. Composition of utilised agricultural area (UAA) 2005-2016 in Lithuania. Total numbers show the total UAA in hectares. Categories are represented in percentages of the total UAA as of each year.

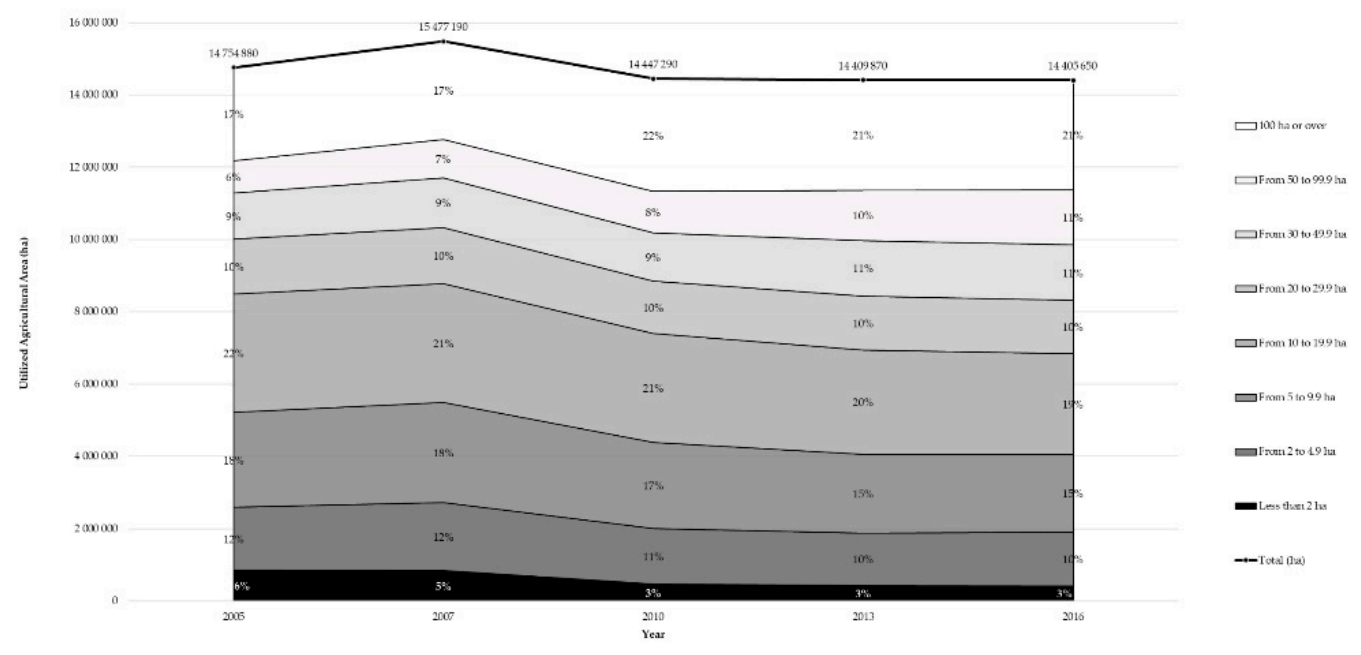

Figure A7. Composition of utilised agricultural area (UAA) 2005-2016 in Poland. Total numbers show the total UAA in hectares. Categories are represented in percentages of the total UAA as of each year. 


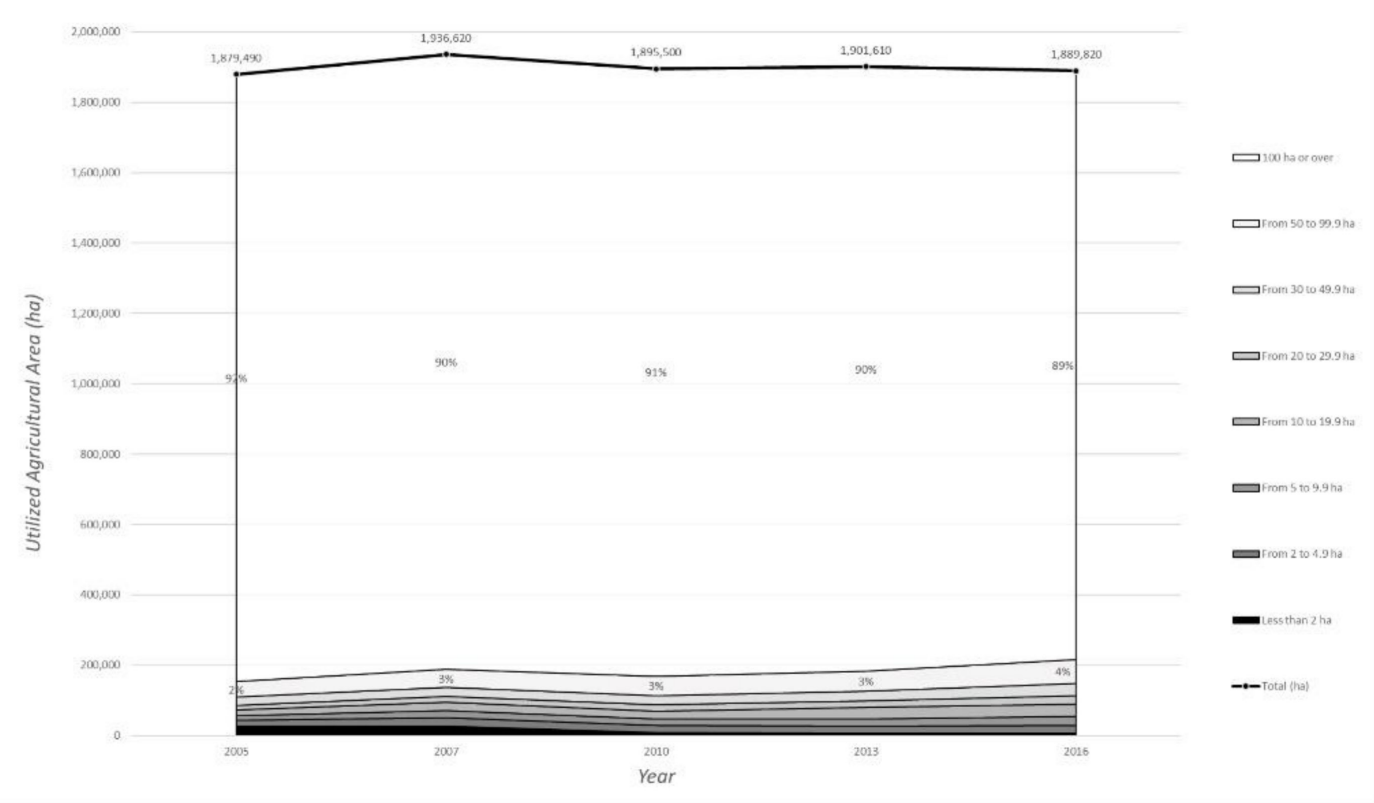

Figure A8. Composition of utilised agricultural area (UAA) 2005-2016 in Slovakia. Total numbers show the total UAA in hectares. Categories are represented in percentages of the total UAA as of each year.

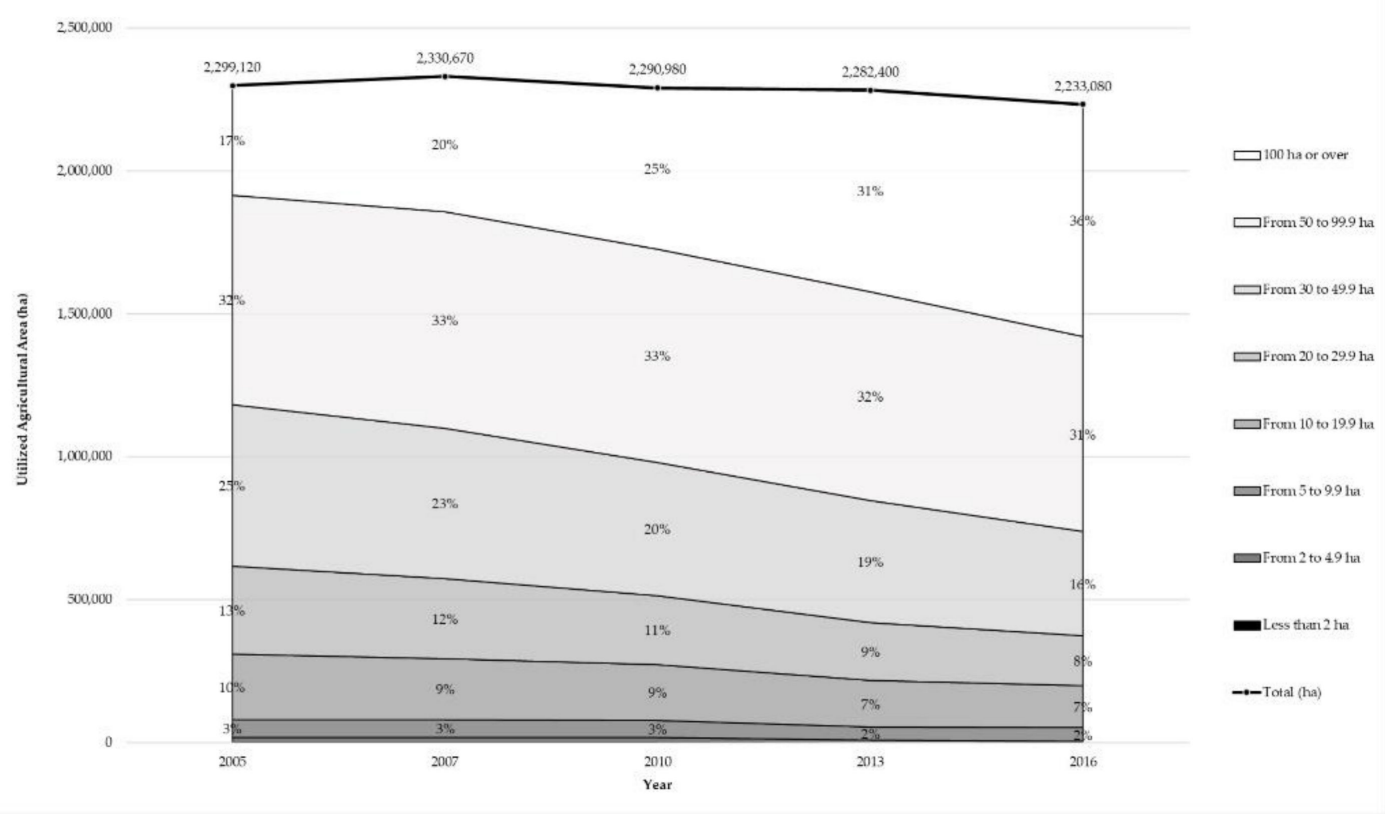

Figure A9. Composition of Uutilised agricultural area (UAA) 2005-2016 in Finland. Total numbers show the total UAA in hectares. Categories are represented in percentages of the total UAA as of each year. 


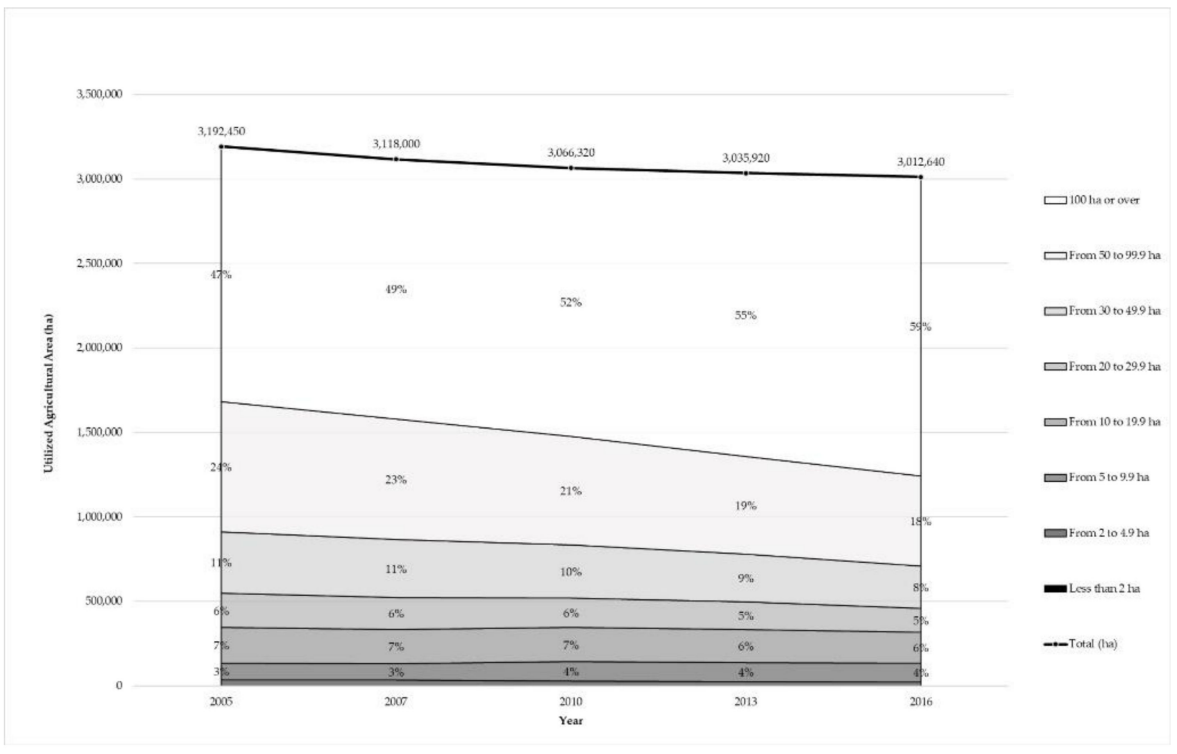

Figure A10. Composition of utilised agricultural area (UAA) 2005-2016 in Sweden. Total numbers show the total UAA in hectares. Categories are represented in percentages of the total UAA as of each year.

\section{References}

1. Fedoroff, N.V. Food in a future of 10 billion. Agric. Food Secur. 2015, 4, 11. [CrossRef]

2. Food and Agricultural Organization. How to Feed the World in 2050; FAO Headquarters: Rome, Italy, 2009.

3. Vermeulen, S.J.; Campbell, B.M.; Ingram, J.S.I. Climate Change and Food Systems. Annu. Rev. Environ. Resour. 2012, 37, 195-222. [CrossRef]

4. Aleklett, K. Peak Oil and the Evolving Strategies of Oil Importing and Exporting Countries; OECD Publishing: Uppsala, Sweden, 2007. [CrossRef]

5. Hermele, K. Land Matters: Agrofuels, Unequal Exchange, and Appropriation of Ecological Space; Human Ecology Division, Lund University: Lund, Sweden, 2012.

6. Cordell, D.; Drangert, J.-O.; White, S. The story of phosphorus: Global food security and food for thought. Glob. Environ. Chang. 2009, 19, 292-305. [CrossRef]

7. Almås, R.; Campbell, H. Rethinking Agricultural Policy Regimes: Food Security, Climate Change and the Future Resilience of Global Agriculture; Emerald Group Publishing Limited: Bingley, UK, 2012. [CrossRef]

8. OECD; Food and Agriculture Organization of the United Nations. OECD-FAO Agricultural Outlook 2012; OECD Publishing: Paris, France, 2012; ISBN 978-92-64-17302-6.

9. Altieri, M.A.; Nicholls, C.I. Agroecology and the emergence of a post COVID-19 agriculture. Agric. Hum. Values 2020, 1-2. [CrossRef] [PubMed]

10. Food and Agricultural Organization. Q and A: COVID-19 Pandemic-Impact on Food and Agriculture. Available online: http://www.fao.org/2019-ncov/q-and-a/impact-on-food-and-agriculture/en/ (accessed on 1 June 2020).

11. Anthem, P. Risk of Hunger Pandemic as Coronavirus Set to Almost Double Acute Hunger by End of 2020. Available online: https://insight.wfp.org/covid-19-will-almost-double-people-in-acute-hunger-by-end-of2020-59df0c4a8072 (accessed on 1 June 2020).

12. Benke, K.; Tomkins, B. Future food-production systems: Vertical farming and controlled-environment agriculture. Sustain. Sci. Pract. Policy 2017, 13, 13-26. [CrossRef]

13. Horlings, L.G.; Marsden, T.K. Towards the real green revolution? Exploring the conceptual dimensions of a new ecological modernisation of agriculture that could 'feed the world.'. Glob. Environ. Chang. 2011, 21, 441-452. [CrossRef]

14. Romeo, D.; Vea, E.B.; Thomsen, M. Environmental Impacts of Urban Hydroponics in Europe: A Case Study in Lyon. Procedia CIRP 2018, 69, 540-545. [CrossRef] 
15. Altieri, M.A.; Nicholls, C.I.; Henao, A.; Lana, M.A. Agroecology and the design of climate change-resilient farming systems. Agron. Sustain. Dev. 2015, 35, 869-890. [CrossRef]

16. Berg, P.G.; Eriksson, T.; Granvik, M. Micro-comprehensive planning in Baltic Sea urban local areas. Proc. Inst. Civ. Eng.-Eng. Sustain. 2010, 163, 219-232. [CrossRef]

17. Berg, P.G.; Granvik, M.; Hedfors, P. Functional Density-A Conceptual Framework in a Townscape Areas Context. Nord. J. Archit. Res. 2012, 2, 29-42.

18. Berg, P.G.; Rydén, L. Urbanisation and Urban-Rural Cooperation. In Rural Development and Land Use; Rydén, L., Karlsson, I., Eds.; Baltic University Press: Uppsala, Sweden, 2012; pp. 141-154. ISBN 978-91-86189-11-2.

19. Granvik, M. The Localization of Food Systems-An Emerging Issue for Swedish Municipal Authorities. Int. Plan. Stud. 2012, 17, 113-124. [CrossRef]

20. Granvik, M.; Jacobsson, T.; Germundsson, L.B.; Larsson, A. The approach of Swedish municipalities to the preservation of agricultural land in a planning context. Int. J. Agric. Resour. Gov. Ecol. 2015, 11, 190. [CrossRef]

21. Granvik, M.; Hedfors, P. Evergreen Issues of planning? Learning from history for sustainable urban-rural systems landscapes Research . Eur. J. Spat. Dev. 2015, Briefing No. 5. 1-21. Available online: http: //www.nordregio.se/Global/EJSD/Researchbriefings/article5.pdf (accessed on 20 July 2020).

22. Roseland, M.; Soots, L. Strengthening local economies. In 2007 State of the World: Our Urban Future; Starke, L., Ed.; WW Norton: New York, NY, USA, 2007; pp. 152-171.

23. Seitzinger, S.P.; Svedin, U.; Crumley, C.L.; Steffen, W.; Abdullah, S.A.; Alfsen, C.; Broadgate, W.J.; Biermann, F.; Bondre, N.R.; Dearing, J.A.; et al. Planetary Stewardship in an Urbanizing World: Beyond City Limits. AMBIO 2012, 41, 787-794. [CrossRef] [PubMed]

24. Food and Agricultural Organization. Food Security-Policy Brief 2006. Issue 2. Available online: http: //www.fao.org/fileadmin/templates/faoitaly/documents/pdf/pdf_Food_Security_Cocept_Note.pdf (accessed on 1 June 2020).

25. Food and Agricultural Organization. Chapter 2. Food security: Concepts and Measurement. Available online: http://www.fao.org/3/y4671e/y4671e06.htm (accessed on 1 June 2020).

26. FAO; IFAD; WFP. The State of Food Insecurity in the World 2015; Meeting the 2015 International Hunger Targets: Taking Stock of Uneven Progress; Food and Agriculture Organization of the United Nations: Rome, Italy, 2015.

27. Global Network against Food Crises Global Report on Food Crises 2020-World. Available online: https: //reliefweb.int/sites/reliefweb.int/files/resources/GRFC_2020_KM_200420.pdf (accessed on 1 June 2020).

28. Ansah, I.G.K.; Gardebroek, C.; Ihle, R. Resilience and household food security: A review of concepts, methodological approaches and empirical evidence. Food Secur. 2019, 11, 1187-1203. [CrossRef]

29. Holling, C.S. Resilience and Stability of Ecological Systems. Annu. Rev. Ecol. Syst. 1973, 4, 1-23. [CrossRef]

30. Davoudi, S.; Shaw, K.; Haider, L.J.; Quinlan, A.E. Resilience: A Bridging Concept or a Dead End? Plan. Theory Pract. 2012, 13, 299-333. [CrossRef]

31. Evans, J.P. Resilience, ecology and adaptation in the experimental city. Trans. Inst. Br. Geogr. 2011, 36, 223-237. [CrossRef]

32. Constas, M.; Frankenberger, T.; Hoddinott, J. Resilience Measurement Principles: Toward an Agenda for Measurement Design; Resilience Measurement Technical Working Group, Technical Series 1; Security Information Network: Rome, Italy, 2014.

33. D'Errico, M.; Garbero, A.; Constas, M. Quantitative Analyses for Resilience Measurement: Guidance for Constructing Variables and Exploring Relationships among Variables: Resilience Measurement Technical Working Group: Technical Series No. 7. Available online: https://www.fsinplatform.org/sites/default/files/ paragraphs/documents/FSIN_TechnicalSeries_7_3.PDF (accessed on 20 July 2020).

34. Pingali, P.; Alinovi, L.; Sutton, J. Food security in complex emergencies: Enhancing food system resilience. Disasters 2005, 29, S5-S24. [CrossRef]

35. Kahiluoto, H.; Berg, P.G.; Granstedt, A.; Fisher, H.; Thomsson, O. The Power of Local: Sustainable Food Systems around the Baltic Sea: Interdisciplinary Synthesis of the BERAS Project; Centre for Sustainable Agriculture Swedish University of Agricultural Sciences: Uppsala, Sweden, 2006; ISBN 978-91-576-7160-8.

36. Allen, P.; FitzSimmons, M.; Goodman, M.; Warner, K. Shifting plates in the agrifood landscape: The tectonics of alternative agrifood initiatives in California. J. Rural Stud. 2003, 19, 61-75. [CrossRef]

37. DeLind, L.B. Place, work, and civic agriculture: Common fields for cultivation. Agric. Hum. Values 2002, 19, 217-224. [CrossRef] 
38. DuPuis, E.M.; Goodman, D. Should we go “home” to eat?: Toward a reflexive politics of localism. J. Rural Stud. 2005, 21, 359-371. [CrossRef]

39. Renting, H.; Van Der Ploeg, J.D. Reconnecting nature, farming and society: Environmental cooperatives in the Netherlands as institutional arrangements for creating coherence. J. Environ. Policy Plan. 2001, 3, 85-101. [CrossRef]

40. Béné, C.; Wood, R.G.; Newsham, A.; Davies, M. Resilience: New utopia or new tyranny? Reflection about the potentials and limits of the concept of resilience in relation to vulnerability reduction programmes. IDS Work. Pap. 2012, 2012, 1-61. [CrossRef]

41. Folke, C.; Carpenter, S.R.; Walker, B.; Scheffer, M.; Chapin, T.; Rockström, J. Resilience Thinking: Integrating Resilience, Adaptability and Transformability. Ecol. Soc. 2010, 15, 20. [CrossRef]

42. Gunderson, L.H.; Holling, C.S. Panarchy: Understanding Transformations in Human and Natural Systems; Island Press: Washington, DC, USA, 2002; ISBN 978-1-55963-857-9.

43. Urban agriculture: Landscapes connecting people, food and biodiversity. 2014. Available online: https: //www.iucn.org/sites/dev/files/import/downloads/urbes_factsheet_07_web.pdf (accessed on 1 June 2020).

44. Bengs, C.; Schmidt-Thomé, K. Urban-rural relations in Europe. EPSON 1.1.2 Final Report. Available online: https://www.espon.eu/sites/default/files/attachments/fr-1.1.2_revised-full_31-03-05.pdf (accessed on 20 July 2020).

45. European Environment Agency. The European Environment-State and Outlook 2010: Synthesis. Available online: https://www.eea.europa.eu/soer/2010/synthesis/synthesis (accessed on 1 June 2020).

46. Nuissl, H.; Haase, D.; Lanzendorf, M.; Wittmer, H. Environmental impact assessment of urban land use transitions-A context-sensitive approach. Land Use Policy 2009, 26, 414-424. [CrossRef]

47. European Commission. 'Guidelines on Best Practice to Limit, Mitigate or Compensate Soilsealing', European Commission Staff Working Document; Publications office of the European Union: Luxembourg, Luxembourg, 2012.

48. REGULATION 1305/2013 of the European Parliament and of the council of 17 december 2013 on support for rural development by the European Agricultural Fund for Rural Development (EAFRD) and repealing Council Regulation (EC) No 1698/2005. Available online: https://eur-lex.europa.eu/legal-content/EN/TXT/ HTML/?uri=CELEX:32013R1305\&from=SV (accessed on 20 July 2020).

49. European Commission. Factsheet on 2014-2020 Rural Development Programme for Poland 2014. Available online: https://ec.europa.eu/info/sites/info/files/food-farming-fisheries/key_policies/documents/ rdp-factsheet-poland_en.pdf (accessed on 20 July 2020).

50. Treaty Establishing the European Economic Community (Rome, 25 March 1957). Available online: https://www.cvce.eu/en/obj/treaty_establishing_the_european_economic_community_rome_25_march_ 1957-en-cca6ba28-0bf3-4ce6-8a76-6b0b3252696e.html (accessed on 20 July 2020).

51. Burkitbayeva, S.; Swinnen, J. Smallholder agriculture in transition economies. J. Agrar. Chang. 2018, 18, 882-892. [CrossRef]

52. Granvik, M.; Lindberg, G.; Stigzelius, K.-A.; Fahlbeck, E.; Surry, Y. Prospects of multifunctional agriculture as a facilitator of sustainable rural development: Swedish experience of Pillar 2 of the Common Agricultural Policy (CAP). Nor. Geogr. Tidsskr.-Nor. J. Geogr. 2012, 66, 155-166. [CrossRef]

53. Buller, H.; Wilson, G.A.; Höll, A. Introduction: The emergence of regulation 2078. In Agri-Environmental Policy in the European Union; Routledge: London, UK, 2017; pp. 1-8. ISBN 9781315204390.

54. Diakosavvas, D. Coherence of Agricultural and Rural Development Policies: The Development Dimension; Organisation for Economic Co-operation and Development: Paris, France, 2006; ISBN 92-64-02388-7.

55. Trouvé, A.; Berriet-Solliec, M.; Déprés, C. Charting and theorising the territorialisation of agricultural policy. J. Rural Stud. 2007, 23, 443-452. [CrossRef]

56. Rockström, J.; Steffen, W.; Noone, K.; Persson, Å.; Chapin, F.S., III; Lambin, E.; Lenton, T.M.; Scheffer, M.; Folke, C.; Schellnhuber, H.J.; et al. Planetary Boundaries: Exploring the Safe Operating Space for Humanity. Ecol. Soc. 2009, 14. [CrossRef]

57. Bengtsson, R. An EU Strategy for the Baltic Sea Region: Good Intentions Meet Complex Challenges; Swedish Institute for European Policy Studies (SIEPS): Stockholm, Sweden, 2009.

58. Rydén, L. The Baltic Sea Region and the Relevance of Regional Approaches. In The Baltic Sea Region: Cultures, Politics, Societies; Maciejewski, W., Ed.; Baltic University Press: Uppsala, Sweden, 2002; pp. 7-29. ISBN 91-973579-8-7. 
59. СНГ; И.К. МежправительственныйСовет по ВопросамАгропромышленного Комплекса СHГ. Available online: http://cis.minsk.by/page/2386 (accessed on 20 July 2020).

60. Van Zanten, B.T.; Verburg, P.H.; Espinosa, M.; Gomez-y-Paloma, S.; Galimberti, G.; Kantelhardt, J.; Kapfer, M.; Lefebvre, M.; Manrique, R.; Piorr, A.; et al. European agricultural landscapes, common agricultural policy and ecosystem services: A review. Agron. Sustain. Dev. 2014, 34, 309-325. [CrossRef]

61. Eurostat Agricultural Labour Input Statistics: Absolute Figures (1000 Annual Work Units) (aact_ali01). Available online: https://appsso.eurostat.ec.europa.eu/nui/show.do?dataset=aact_ali01\&lang=en (accessed on 13 May 2020).

62. Eurostat Arable Crops: Number of Farms and Areas of Different Arable Crops by Agricultural Size of Farm (UAA) and Size of Arable Area (ef_Alarableaa). Available online: https://appsso.eurostat.ec.europa.eu/nui/ show.do?dataset=ef_alarableaa\&lang=en (accessed on 13 May 2020).

63. Eurostat. Eurostat Statistics Explained; Glossary: Utilised Agricultural Area (UAA). Available online: https://ec.europa.eu/eurostat/statistics-explained/index.php?title=Glossary:Utilised_agricultural_ area_(UAA) (accessed on 13 May 2020).

64. Eurostat Statistics Explained; Glossary: Agricultural Holding. Available online: https://ec.europa.eu/eurostat/ statistics-explained/index.php/Glossary:Agricultural_holding (accessed on 13 May 2020).

65. Eurostat Statistics Explained; Glossary: Annual Working Unit. Available online: https://ec.europa.eu/eurostat/ statistics-explained/index.php/Glossary:Annual_work_unit_\%28AWU\%29 (accessed on 13 May 2020).

66. Fałkowski, J. Together we stand, divided we fall? Smallholders' access to political power and their place in Poland's agricultural system. J. Agrar. Chang. 2018, 18, 893-903. [CrossRef]

67. Chmieliński, P.; Karwat-Woźniak, B. Changes in Population and Labour Force in Family Farming in Poland. Available online: https://ageconsearch.umn.edu/record/231522 (accessed on 17 June 2020).

68. Žakevičiūtè, R. Rural Livelihood Diversification: A Solution for Poverty in the Post-Soviet Rural Baltic States? Sociol. Rural. 2019, 59, 560-580. [CrossRef]

69. Flygare, I.; Isacson, M. The tension between modernity and reality 1945-2010. In Agrarian History of Sweden: From 4000 BC to AD 2000; Nordic Academic Press: Lund, Sweden, 2011; ISBN 9789185509560.

70. Ihse, M. Swedish agricultural landscapes-patterns and changes during the last 50 years, studied by aerial photos. Landsc. Urban Plan. 1995, 31, 21-37. [CrossRef]

71. Granvik, M.; Joosse, S.; Hunt, A.; Hallberg, I. Confusion and Misunderstanding-Interpretations and Definitions of Local Food. Sustainability 2017, 9, 1981. [CrossRef]

72. Graham, L.P. Climate change effects on river flow to the Baltic Sea. AMBIO J. Hum. Environ. 2004, 33, $235-242$. [CrossRef]

73. IPCC. Summary for Policymakers. In Global Warming of $1.5^{\circ} \mathrm{C}$. An IPCC Special Report on the Impacts of Global Warming of $1.5^{\circ} \mathrm{C}$ Above Pre-Industrial Levels and Related Global Greenhouse Gas Emission Pathways, in the Context of Strengthening the Global Response to the Threat of Climate Change, Sustainable Development, and Efforts to Eradicate Poverty; Masson-Delmotte, V., Zhai, P., Pörtner, H.-O., Roberts, D., Skea, J., Shukla, P.R., Pirani, A., Moufouma-Okia, W., Péan, C., Pidcock, R., et al., Eds.; World Meteorological Organization: Geneva, Switzerland, 2018.

74. Parry, M.A.J.; Hawkesford, M.J. Food security: Increasing yield and improving resource use efficiency. Proc. Nutr. Soc. 2010, 69, 592-600. [CrossRef]

75. Wegren, S.K. Can Russia's food exports reach $\$ 45$ billion in 2024? Post-Communist Econ. 2020, 32, 147-175. [CrossRef]

76. Swinnen, J.; Herck, K.V. Food Security and Sociopolitical Stability in Eastern Europe and Central Asia; Oxford University Press: Oxford, UK, 2013; ISBN 978-0-19-175843-0.

77. Altieri, M.A.; Funes-Monzote, F.R.; Petersen, P. Agroecologically efficient agricultural systems for smallholder farmers: Contributions to food sovereignty. Agron. Sustain. Dev. 2012, 32, 1-13. [CrossRef]

78. Tscharntke, T.; Clough, Y.; Wanger, T.C.; Jackson, L.; Motzke, I.; Perfecto, I.; Vandermeer, J.; Whitbread, A. Global food security, biodiversity conservation and the future of agricultural intensification. Biol. Conserv. 2012, 151, 53-59. [CrossRef] 
79. Heinemann, J.A.; Massaro, M.; Coray, D.S.; Agapito-Tenfen, S.Z.; Wen, J.D. Sustainability and innovation in staple crop production in the US Midwest. Int. J. Agric. Sustain. 2014, 12, 71-88. [CrossRef]

80. European Parliament. Short Food Supply Chains and Local Food Systems in the EU-Think Tank. Available online: https://www.europarl.europa.eu/thinktank/en/document.html?reference=EPRS_BRI (accessed on 18 June 2020).

(C) 2020 by the authors. Licensee MDPI, Basel, Switzerland. This article is an open access article distributed under the terms and conditions of the Creative Commons Attribution (CC BY) license (http://creativecommons.org/licenses/by/4.0/). 